\title{
Investigating Teachers Gender Stereotyped Performance in Beirut Private Schools
}

\author{
Dr Mona Mohamad Taher Tahseldar \\ Associate Professor in English Education, Lebanon \\ *Corresponding Author: Dr Mona Mohamad Taher Tahseldar, Associate Professor in English \\ Education, Lebanon
}

\begin{abstract}
The present study aimed at exploring the gender-stereotyped beliefs, practices and awareness of 131 teachers employed at a community of six private schools guided by a religious charity association in Beirut, Lebanon. About Ifegbesan (2010) Teacher's Gender Stereotype Questionnaire was adopted to evaluate the extent of these teachers gender stereotyped behaviors in the private school classrooms. The responses generated from filling the questionnaires via e-mails formed the collected data. The study employed SPSS to deduce the results and analyze them through descriptive statistics, ANOVA and T-Test. The indicated outcomes and results revealed variance in levels of gender-stereotyped behaviors among the surveyed teachers. ANOVA test results disclosed that teachers'variables demonstrated in demography, gender and years of experience had no statistically significance in affecting teachers' gender-stereotyped beliefs, practices and awareness. The findings uncovered the necessity of helping teachers in acquiring the knowledge and awareness in order to avoid the negative effect of the gender stereotyping and its sensitivity while dealing with learners. Moreover, results presented a call for all educators headed by the ministry of Education to develop textbooks and materials, establish mechanisms to monitor and evaluate education policy implementation from a gender equality perspective.
\end{abstract}

Keywords: Gender stereotypes, teachers`beliefs, teachers`practices, teachers`awareness

\section{INTRODUCTION}

According to Gender Equality Commission of Europe Council (2015), Gender Stereotypes are the fixed perceptions about males and females` traits and capabilities designed to guide people behavior based on their gender. Many examples could be derived from literature concerning this social inherited issue. For instance, the commonly held belief is that men tolerate hard work more than women. This example is considered a positive stereotype for men but a negative one for women because it indicates that they lack natural hard working skills while men are born for hard working professions. Such a stereotype could lead to discrimination in hiring practices, schooling, teaching, and in many other social situations. Hall et al., (1988) defined stereotypes as personifications which are widely accepted and shared among members of a given society and handed down from generation to another. Meanwhile, Fung and Ma (2000) asserted that gender stereotyping is a subjective perception, which may be an intuition, a prejudice, an imagination, or a past impression of what a person has been before. Therefore, the expression of Gender Stereotype has been identified by the differences between sexes whereby males and females are arbitrarily assigned by roles determined for each gender according to the society beliefs and practices. These social rooted beliefs of gender stereotyped practice and awareness reflect the society expectations inherited from parents steering their children toward life choices that are deemed to be suitable for their gender. These parent beliefs and practices to Bertrand (2011), Bertrand and Hallock (2001), Blau, Ferber and Winkler (2002), and Fortin (2005), may in large part be contributed to determine the gender gaps that confirm the gender stereotype role in beliefs, practice and awareness. Accordingly, Bisin and Verdier (2000) found that the transmission of preferences and beliefs of families had the earliest impact on the development of their children's cognitive and social development. In the same sense, Farre and Vella (2007), Johnston et al. (2014) claimed that this transmission is usually expressed in the didactic teaching either directly or indirectly influencing the teachers' styles in terms of teaching and tackling tasks, responsibilities, gender language, behavior, thinking and practice that affect students' behaviors and outcomes through 
a variety of mechanisms. Consequently, once the child starts school many factors contribute to the formation of his complex broadened beliefs and attitudes produced from the interaction of parents beliefs, concepts and practice with those of peers and teachers. Teachers were considered as significant figures of authority to students, they definitely will affect students` by their beliefs and the way they act in class. Accordingly, Lavy (2008) has found that most teachers reflected their beliefs in actual classroom practices through their different feedback on students` performance, question answers, and even in grading the exams.

\subsection{Problem Statement}

The gap between the two genders (male and female) has existed over the years and reflected many hard efforts made by governments and organizations to address and lessen this problematic aspect. These efforts included UN (2000), UNDP (2001), and CEDAW (1981) announcements for women`s rights and the elimination of all forms of discrimination between genders, as well as criticized the unequal treatment between sexes and the stereotyped approaches conducted in the educational system. The gender stereotype problem is experienced and practiced in all human societies, endeavors, professions, careers, work places, homes, schools and other various institutions. Halverson (1981) realized various types of gender stereotypes in most societies like self-stereotyping, school stereotyping and family/cultural stereotyping. For instance, Fiske, (1993) and Stangor \& Lange, (1994) regard men as intellectually competent, strong and brave, while women are homely, warm and expressive, incompetent and passive. All contemporary societies and the educational systems are addressing the gender inequality in all social systems, and trying to develop this gender sensitivity in future generations; however, we still find that -gender stereotyping is rooted deeply in most of our Arab communities and directly or indirectly affect the academic life inside institutions. Nevertheless, teachers form a part of the weave of these communities and societies and their perceptions are derived from their surroundings and environments, they will in turn reflect their gender stereotype beliefs, practices and awareness in class, which might lead to unthankful results.

\subsection{Study Questions}

The study was guided by the following three questions;

1- How do private school teachers perceive their gender stereotyped beliefs` performance in private school classrooms?

2- What is the extent of the teachers` gender stereotyped practices in Beirut private school classrooms?

3- Are teachers aware of the requirements to avoid gender stereotyping students in private schools?

4- What is the correlation between the participants` gender and experience with their beliefs, practices and awareness?

\subsection{Purpose and Significance}

The teachers' role is changing, so how can we effectively ensure that our teachers are meeting the ever increasing demands of their jobs? This study main objective was to investigate the private school teachers`gender stereotyped behavior weaknesses and strengths through their perceptions in leading the Lebanese private school classrooms. In other words, the main purpose of this study was to provide data concerning the participant teachers in terms of their gender stereotyped beliefs, practices and awareness conducted in their classes. Thus, conclusions can be drawn regarding gender stereotyped practices of teachers in Beirut Lebanon private schools with the aim of highlighting their gaps and raising their awareness to this important issue that has negative consequences on our future generations as well as providing them with constructive feedback. In return, it will help school teachers play a key role in narrowing this gender sensitivity from future generation beliefs and practice, when their gender stereotyping beliefs practices and awareness gaps are identified. Finally, to the researcher knowledge, it is the first paper that discussed the teachers gender stereotyped behaviors in terms of their beliefs, practices and awareness in this private religious community schools.

\section{LiTERATURE REVIEW}

According to the Psychological Glossary, the international human rights law framework is concerned with gender stereotypes and stereotyping that affects human rights negatively. For more details, 
gender stereotype is a generalized view about the characteristics or the roles that should be performed by females and males which become harmful when it limits either of the genders` capacity to develop their personal abilities, or chase their professional careers and make choices about their lives and life plans. Gender stereotyping can be both positive and negative when it comes to motherhood for child nurture responsibilities fall exclusively on mothers. Thus, gender stereotyping refers to an individual specific attributes, characteristics, or roles designed for her or his membership by their society, which is leading to violation of human rights books

As a result of the gender stereotype consequences, the international human rights law placed a legal obligation to eliminate discrimination between women and men in all areas of their lives. This obligation requires governments to take measures to address gender stereotypes both in public and private life. The Convention on the Elimination of All Forms of Discrimination provided in article 5 that, State Parties shall take all appropriate measures to modify the social and cultural patterns of conduct of men and women, with a view to achieving the elimination of prejudices and customs and all other practices which are based on the idea of the inferiority or the superiority of either of the sexes or on stereotyped roles for men and women.

Since late 1970s, gender issues in education were associated principally with a focus on the achievements and aspirations of girls, in order to redress the power imbalance in favor of boys and men OECD (2001). Although, recently gender issues in education have come to be equated with boys' underperformance in examinations, and a so-called crisis of masculinity, the gender stereotyping teachers continued judging female students` success in Sciences or Math as indicated in Chetcuti's (2009) Maltese study, as a behavioral issue rather than cognitive or intellectual. Accordingly, in 2006, Skolverket (2006a) claimed that at the compulsory school girls achieved better grades in all subjects except Physical Education and Health. However, as pointed out in this Swedish study, they did not mean that all boys failed with their education or that all girls achieved good educational results. Thus, it is obvious through many studies results that both girl and boy students can achieve in the same way when the suitable educational environment is afforded.

Theories of teaching and learning have long emphasized the important role that teachers can play in supporting students' development in areas beyond achievement. Pianta and Hamre (2009) stated that affording a high quality teaching requires providing students with the necessary emotional support that could be achieved by creating a consistent safe environment in which teachers can help students become more self-reliant, motivated to learn, and willing to be risk takers. As mentioned by Wentzel (2003), students with high self-esteem are more likely to set higher goals, while to Orth, Robins, \& Widaman, (2012) teachers are responsible about creating a positive relationship with their students, so they can be more self-confident with high self-esteem and positive sense of self. They added that students need to have positive relationships with their peers during schooling and future educational and occupational outcomes, which cannot be achieved without a supportive fair teacher. Thus, a wide range of literature discussed the impact of teacher's practices, beliefs and awareness on students positive sense of self and self-esteem. Consequently, the teachers` gender stereotype beliefs, practices and awareness to many authors affect students` self-esteem that help them to be successful in all life fields. However, most of the studies conducted in many developed countries found that the majority were preoccupied with gender-stereotype especially at schools where students were genderstereotyped in textbooks, achievement and performance Mirza, et al.(2006)White \& White (2006); or by teachers` gender stereotyped beliefs, awareness and practices (Diekman \& Eagly, 2000; Subrahmanian, 2002; Marshall \& Arnot, 2008; and Lopez Saez, et al. 2008). In consistency with many researchers, Tiedemann (2002) studied the effect of the teachers' gender stereotypes in terms of their beliefs of students' mathematics abilities and found that most tested teachers` perceptions were consistent with stereotypes of gender differences. This bias in teachers' gender stereotyped perceptions and beliefs of students' abilities can be referred to their homes and schools 'environment, regarding the supremacy of males on females in many education courses that require mental abilities. Therefore, many factors played important role in constructing these gender stereotype beliefs awareness and practices; Jones and Dindia (2004) in their meta analysis study examined patterns of sex differences in teacher student interactions and found that teachers initiate more negative interactions with male students than with female ones. In the same sense (Erinosho, 2005; Azikwe, 2002; Aladejana, 2002; Mkuchu 2003; Aladejana (2002) found that school Curricula activities favor boys more than girls creating gender inequality in students` learning, while Ogunbanwo (1998) 
textbooks analysis demonstrated that all authors were males and included greater number of male generic words than females, as well as females were portrayed as traders, hairdresser, and secretary, while males were represented in skillful professions like doctors, scientists, engineers, and so on. In a related study, Biraimah (1982) examined the teacher-student interaction patterns in a co-education school, and was able to realize that teachers had negative regard for the abilities of female students while males were accredited positively. From these reviews, it could be inferred that most studies have focused on content analysis of textbooks and curriculum materials and gender differentiation in academic achievements while teachers` gender stereotyped beliefs, awareness and classroom practices have been neglected. In general, there is a lack of teachers ' gender stereotype research especially in the Arab world and specifically in Lebanon. However, it has become a priority to develop studies oriented toward understanding the nature of teacher-student classroom interaction. Such priority has been reflected in the conducted researches that described and analyzed the effects of the teachers' gender-stereotyping beliefs and behavior on students emotional states in learning and behaving. Most researches`results (Sadker, 2001; Jones \& Dindia, 2004; Razumnikova, 2005; Calvanese, 2007; Hoang, 2008; Lopes-Saez et al, 2008) indicated that teachers' personal beliefs and stereotypical perceptions affect their attitudes and their classroom practices that can affect students of both genders either negatively or positively. According to Sadker \& Sadker (1986) many teachers function in their classes according to their preconceptions of skills, behavior, and performance of girls and boys. Cahill and Adams (1997) conducted a study to explore early childhood teachers' beliefs and attitudes toward gender roles and found that while early childhood teachers express some openness to children exploring gender roles, teachers generally felt more comfortable with girls, rather than boys, exploring both male and female gender roles. A significant positive relationship has also been found by Peterson, et al. (1989) among teachers' beliefs, teachers' practices and students' problem solving achievement. Booth and Nolen (2012), Niederle and Vesterlund (2011), Alan and Ertac (2016) proposed creative action, quotas, educational programs targeting non cognitive skills, mentoring and single-sex schooling to diminish the gender differences gaps resulted from the school and family gender stereotyping beliefs. Similarly, Hyde and Merk (2009) and Gray et al. (2004) stated that it has been documented that most of the observed gender differences in self esteem and achievement were due to the cultural environment. As a result of the reported positive relationship between teachers' beliefs, practices and awareness with students' enhancement of sense of self, and self esteem, as well to improve the quality of teaching and learning, researchers need to understand the nature of teachers' gender perspectives toward their classroom practices and beliefs.

In the context of the current paper, teachers' awareness, beliefs and practices of gender stereotype have been studied and linked to differences in sociocultural measures of gender equity. Our results highlighted the fact of importance of teachers` practices beliefs and awareness in creating a suitable learning environment for students. Thus, through the participant teachers` perceptions the study highlighted the characteristics of the private teachers in Beirut Lebanon in terms of their gender stereotyped beliefs awareness and classroom practices.

\section{RESEARCH METHODOLOGY}

\subsection{Method}

The current study adopted the quantitative research approach and employed survey research, which is highly relevant for exploring beliefs, practices and awareness of people. Following the survey method, this study purpose was to gain a better understanding of Beirut, Lebanon private school teachers' gender-stereotype awareness, beliefs and practices. Moreover, it targeted the comparison between the teachers' obtained characteristics in terms of their beliefs, practices and awareness of gender-stereotype behaviors. Finally, it was to determine the relationship between background demographic variables of teachers`gender and experience with each of the studied teachers` factors of gender stereotype.

\subsection{Participants}

The participants of this study were 131 teachers employed at a community of six private schools guided by a religious association in Beirut during the academic year 2016-2017. The participants were of different sexes as shown in table 0 , wide range of ages as shown in Table $0 \mathrm{~A}$, different educational levels as shown in Table $0 \mathrm{~B}$. They also taught in diverse schools types as shown in table $0 \mathrm{C}$, all levels (K-12) as shown in table $0 \mathrm{D}$. They had various years of experience as shown in Table $0 \mathrm{E}$, and graduates of different majors as shown in Chart 0 . The questionnaire, which was chosen from 
literature and developed by About-Ayodeji, was sent to these teachers' e-mails in order be administered. Out of the 131 teachers, only 104 respondents were considered in this study, for the remaining 27 did not complete the questionnaire and consequently they were excluded.

Table $0 \backslash$ gender

\begin{tabular}{|c|c|c|c|c|c|}
\hline & & Frequency & Percent & Valid Percent & Cumulative Percent \\
\hline \multirow[t]{3}{*}{ Valid } & Male & 15 & 11.5 & 11.5 & 11.5 \\
\hline & Female & 116 & 88.5 & 88.5 & 100.0 \\
\hline & Total & 131 & 100.0 & 100.0 & \\
\hline
\end{tabular}

Table $0 /$ presented the gender division of the participants in the research, 15 males (11.5\%) and 116 female $(88.5 \%)$.

Table 0A\Age

\begin{tabular}{|l|l|r|r|r|r|}
\hline \multicolumn{2}{|c|}{} & \multicolumn{1}{|c|}{ Frequency } & \multicolumn{1}{|c|}{ Percent } & Valid Percent & \multicolumn{1}{c|}{ Cumulative Percent } \\
\hline \multirow{3}{*}{ Valid } & $22-30$ & 43 & 32.8 & 32.8 & 32.8 \\
\cline { 2 - 6 } & $31-40$ & 43 & 32.8 & 32.8 & 65.6 \\
\cline { 2 - 6 } & $41-50$ & 28 & 21.4 & 21.4 & 87.0 \\
\cline { 2 - 6 } & $51-64$ & 17 & 13.0 & 13.0 & 100.0 \\
\cline { 2 - 6 } & Total & 131 & 100.0 & 100.0 & \\
\hline
\end{tabular}

The participant teachers`age, as shown in table 0 A, ranged between 22 and 64 years respectively; $32.8 \%$ of the participant teachers aged between 22 and 30 years old, while $32.8 \%$ were between 31 and 40 years old, $21.4 \%$ were between 41 and 50 years old and $13.0 \%$ were between 51 and 64 years old.

\section{Table 0 B \Education}

\begin{tabular}{|l|l|r|r|r|r|}
\hline \multicolumn{2}{|c|}{} & \multicolumn{1}{|c|}{ Frequency } & Percent & Valid Percent & \multicolumn{1}{|c|}{ Cumulative Percent } \\
\hline \multirow{3}{*}{ Valid } & BA & 79 & 60.3 & 60.3 & 60.3 \\
\cline { 2 - 6 } & MA & 30 & 22.9 & 22.9 & 83.2 \\
\cline { 2 - 6 } & Other & 22 & 16.8 & 16.8 & 100.0 \\
\cline { 2 - 6 } & Total & 131 & 100.0 & 100.0 & \\
\hline
\end{tabular}

Table 0 B demonstrated the participants` level of education, where the majority were BA graduates $(60.3 \%)$, while $22.9 \%$ were MA graduates and $16.8 \%$ were other than BA or MA graduates.

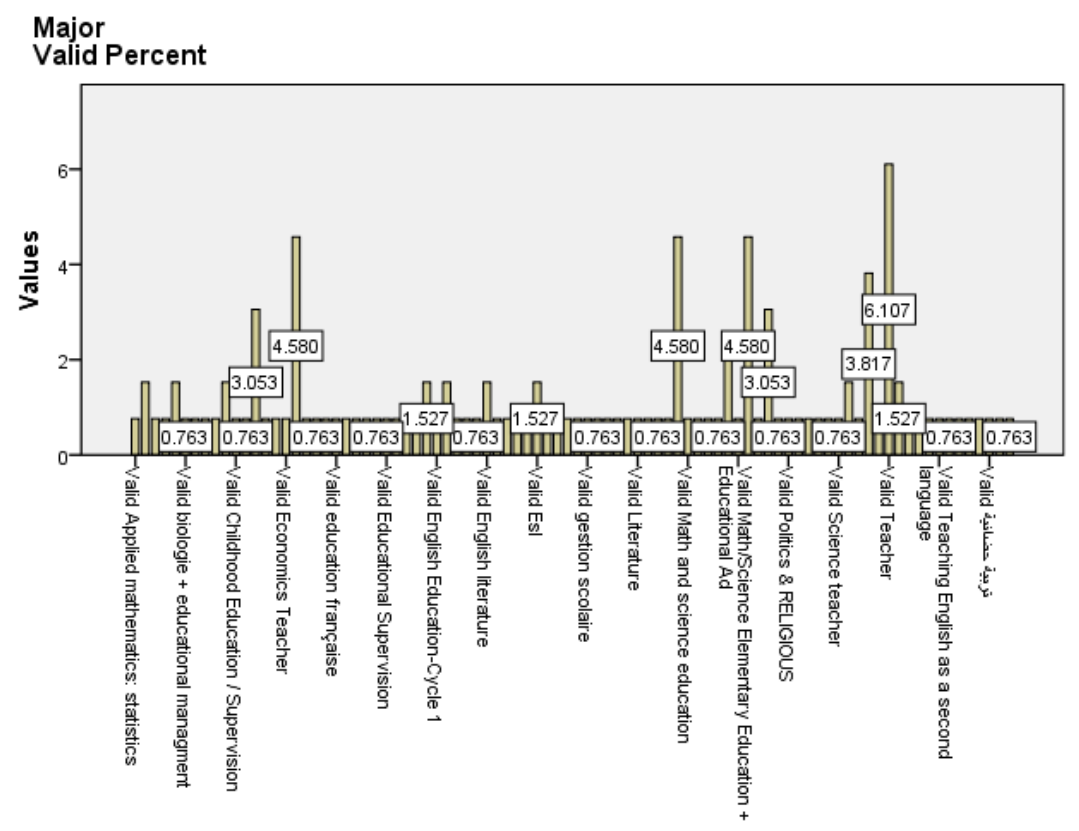

Chart 0

Chart 0 demonstrated the participant teachers` majors, while table $0 \mathrm{C}$ showed that almost all participant belonged to coeducation schools $98.5 \%$. 
Table 0 C School Type

\begin{tabular}{|c|c|c|c|c|c|}
\hline & & Frequency & Percent & Valid Percent & Cumulative Percent \\
\hline \multirow[t]{4}{*}{ Valid } & Male & 1 & .8 & .8 & $\begin{array}{r}8 \\
\end{array}$ \\
\hline & Female & 1 & .8 & .8 & 1.5 \\
\hline & Mixed & 129 & 98.5 & 98.5 & 100.0 \\
\hline & Total & 131 & 100.0 & 100.0 & \\
\hline
\end{tabular}

Table 0C demonstrated the type of schools participants belonged to. The results showed that 129 out of 131participants were teaching in coeducation schools.

Table 0 D \Classes Taught

\begin{tabular}{|c|c|c|c|c|c|}
\hline & & Frequency & Percent & Valid Percent & Cumulative Percent \\
\hline \multirow[t]{5}{*}{ Valid } & Cycle one & 46 & 35.1 & 35.1 & 35.1 \\
\hline & Cycle two & 39 & 29.8 & 29.8 & 64.9 \\
\hline & Cycle three & 20 & 15.3 & 15.3 & 80.2 \\
\hline & Cycle 4 & 26 & 19.8 & 19.8 & 100.0 \\
\hline & Total & 131 & 100.0 & 100.0 & \\
\hline
\end{tabular}

Table 0 E Years of Experience

\begin{tabular}{|c|c|c|c|c|c|}
\hline & & Frequency & Percent & Valid Percent & Cumulative Percent \\
\hline \multirow[t]{3}{*}{ Valid } & $1-3$ & 65 & 49.6 & 49.6 & 49.6 \\
\hline & Other & 66 & 50.4 & 50.4 & 100.0 \\
\hline & Total & 131 & 100.0 & 100.0 & \\
\hline
\end{tabular}

As mentioned before the participants were k- 12 grade teachers, which is equivalent to the Lebanese distribution of education stages: cycle one, two, three, and four with almost similar years of experience ( $49.6 \%$ between 1 and 3 years, and $50.4 \%$ more than 10 years) as indicated in tables $0 \mathrm{D}$ and $0 \mathrm{E}$ above.

\subsection{Instrumentation}

The participants had to answer the About Ifegbesan ( 2010)Teacher Gender Stereotype Questionnaire which consisted of two sections; the first section is related to the teachers demographic and background variables concerning their sex, age, level of education, school sector, school type, class taught, teaching experience and subject of specialization. Through using a Likert-type scale ranging from strongly disagree to strongly agree (1-strongly disagree, 2-disagree, 3 undecided, 4-agree, 5-to strongly agree), the teachers had to answer the second section of the questionnaire which consisted of three parts. The First part included the teachers' beliefs of gender-stereotype through 10 statements where the respondents were asked to state the extent the statement reflect their personal genderstereotyped beliefs. The second part embedded 12 statements to examine the level of the teachers` gender stereotyped practices. Additionally, the third part presented 6 statements to show the extent of the participant teachers`awareness of the needed gender stereotyped changes.

The internal consistency reliability alpha was .82 after a pilot test conducted on a sample of 20 teachers of different levels ages and experiences.

\subsection{Procedure}

After receiving the dean's approval at the Lebanese University, Faculty of Education to conduct the study, we had to visit the head quarter of the assigned community of schools to introduce the study aims and acquire the permission to survey the teachers employed at these schools. With the help of the head of the English language department, the questionnaires were sent through e-mails to all teachers in this community of Beirut private schools (131 teachers). The participants were assured, in a consent letter attached to the questionnaire that their names and the data they provide will remain confidential. A Wide range of literature like (Bettinger and Long (2005), Ho man and Oreopoulos (2009), Carrell et al. (2010), Antecol et al. (2012) whe studied the effects of teachers characteristics in creating a gender stereotyped learning environment and showed that teachers played an important role in the continuity of gender stereotyping in society. In the same sense, the present study discussed theoretically the effects of teachers' gender stereotyped beliefs, practices and attitudes on students' behavior, self-esteem, sense of self, motivation and understanding of gender. Our teachers' gender 
stereotyping features were identified through their answers to the questionnaire according to their own perspectives. The large dataset, collected for the exclusive purpose of this paper was detailed, which helped the researcher to identify Beirut private teachers` characteristics that are not available, according to our information, in any other datasets. To deduce the results, all the returned survey questionnaire were coded on Statistical Package for the social sciences (SPSS) where 27 of them were canceled, after we included their demographic data, as they did not satisfy the recommended completion of this distributed questionnaire. Furthermore, the perceptions of the participant teachers gender-stereotyped beliefs, practices and awareness reflected in their choices of Likert scale ranging from one to five for strongly agree, agree, undecided, disagree and strongly disagree respectively for each statements were scored as responses. In order to examine the relation between the differences occurred in teachers' gender stereotyped beliefs practices and awareness with teachers 'gender and their years of experience, a t-test and an analysis of variances (ANOVA) statistics were employed.

\section{RESUltS AND ANALYSIS}

To answer the study questions a variety of statistical operations were done. Although 131 teachers participated in this study only 104 of the received questionnaires were considered valid to be used in the study as the other 27 were ignored because they were not completed. For Data Analysis the Statistical Package for Social Science SPSS version (15.0) was used to analyze the participants' responses with a minimum alpha probability level of.05. Descriptive statistics, T Test and ANOVA were conducted to determine the teachers extent of gender stereotyped beliefs, practices and awareness in their classrooms, and whether there was any statistical relation between the participants' gender stereotyped behaviour and their gender or years of experience through their perceptions.

1- What is the extent of the teachers' gender stereotyped practices in Beirut private school classrooms?

2- Are teachers aware of the requirements to avoid gender stereotyping students in private schools?

3- What is the correlation between the participants` gender and experience with their beliefs, practices and awareness?

\subsection{Descriptive Statistics}

In order to answer the first question (How do private school teachers perceive their gender stereotyped beliefs through their performance in private school classrooms?) the following descriptive statistical operations were employed.

Tables (1-11) showed the results of the frequencies and percentages, means used to determine the extent of their gender stereotyped beliefs and whether or not there is a statistically significant difference between teachers` performance application of gender stereotyped beliefs in private schools.

Table1. $\backslash 53.8 \%$ disagree

Q1 Boys can handle pressure situations better than girls

\begin{tabular}{|c|c|c|c|c|c|}
\hline \multicolumn{2}{|c|}{} & Frequency & Percent & Valid Percent & Cumulative Percent \\
\hline \multirow{4}{*}{ Valid } & Strongly Agree & 1 & .8 & 1.0 & 1.0 \\
\cline { 2 - 6 } & Agree & 18 & 13.7 & 17.3 & 18.3 \\
\cline { 2 - 6 } & Undecided & 16 & 12.2 & 15.4 & 33.7 \\
\cline { 2 - 6 } & Strongly Disagree & 13 & 9.9 & 12.5 & 46.2 \\
\cline { 2 - 6 } & Disagree & 56 & 42.7 & 53.8 & 100.0 \\
\cline { 2 - 6 } & Total & 104 & 79.4 & 100.0 & \\
\hline Missing & System & 27 & 20.6 & & \\
\hline \multicolumn{7}{|c|}{} & 131 & 100.0 & & \\
\hline
\end{tabular}

Answering the first question teachers` answers shown in table 1 indicated that $52(66,3 \%)$ teachers out of 104 strongly disagree and disagree that boys can handle pressure situations better than girls, 19 of them (18.3\%) agree and strongly agree with the tested statement and $16(12.5 \%)$ were undecided. Although the majority of teachers did not agree that boys can handle more pressure than girls, we that find $30.8 \%$ of the teachers, which is considered an important percentage in education, were undecided and agreed that boys are able to handle pressure more than girls. 
Table2 $\backslash 64.4 \%$ Disagree

Q2: Males are strong and females are weak

\begin{tabular}{|c|c|c|c|c|c|}
\hline \multicolumn{2}{|c|}{} & Frequency & Percent & Valid Percent & $\begin{array}{c}\text { Cumulative } \\
\text { Percent }\end{array}$ \\
\hline \multirow{3}{*}{ Valid } & Strongly Agree & 1 & .8 & 1.0 & 1.0 \\
\cline { 2 - 6 } & Agree & 3 & 2.3 & 2.9 & 3.8 \\
\cline { 2 - 6 } & Undecided & 4 & 3.1 & 3.8 & 7.7 \\
\cline { 2 - 6 } & Strongly Disagree & 29 & 22.1 & 27.9 & 35.6 \\
\cline { 2 - 6 } & Disagree & 67 & 51.1 & 64.4 & 100.0 \\
\cline { 2 - 6 } & Total & 104 & 79.4 & 100.0 & \\
\hline Missing & System & 27 & 20.6 & & \\
\hline \multicolumn{2}{|c|}{} & 131 & 100.0 & & \\
\hline
\end{tabular}

Again table 2 demonstrated the teachers' answers to the second question which indicated that 96 $(92.3 \%)$ teachers out of 104 strongly disagree and disagree that males are strong and females are weak, 4 of them (3.9\%) agree and strongly agree with the tested statement and $4(3.8 \%)$ were undecided. Which-These statistical indications mean that almost all participants did not agree that boys are strong and girls are weak.

\section{Table $\backslash 52.9 \%$ disagree}

Q3 : Male students generally do better in mathematics than female students

\begin{tabular}{|c|c|c|c|c|c|}
\hline \multicolumn{2}{|c|}{} & Frequency & Percent & Valid Percent & $\begin{array}{c}\text { Cumulative } \\
\text { Percent }\end{array}$ \\
\hline \multirow{3}{*}{ Valid } & Strongly Agree & 3 & 2.3 & 2.9 & 2.9 \\
\cline { 2 - 6 } & Agree & 13 & 9.9 & 12.5 & 15.4 \\
\cline { 2 - 6 } & Undecided & 16 & 12.2 & 15.4 & 30.8 \\
\cline { 2 - 6 } & Strongly Disagree & 17 & 13.0 & 16.3 & 47.1 \\
\cline { 2 - 6 } & Disagree & 55 & 42.0 & 52.9 & 100.0 \\
\cline { 2 - 6 } & Total & 104 & 79.4 & 100.0 & \\
\hline Missing & System & 27 & 20.6 & & \\
\hline \multicolumn{1}{|c|}{} & Total & 131 & 100.0 & & \\
\hline
\end{tabular}

Table 3 results presented the teachers`answers for statement 3 where we notice that the majority of the study participants $72(69.2 \%)$ out of 104 disagreed and strongly disagreed thatmale students generally do better in mathematics than female students, 16 of them (15.4\%) agree and strongly agree with the tested statement and $16(15.4 \%)$ were undecided. Although the majority of teachers did not agree that male students generally do better in mathematics than female students, we find that $30.8 \%$ of the teachers were undecided and agreed with the studied statement which means that around one third of the participant believe that males are better in mathematics than females.

Table4\53.8\% disagree

Q4 Boys generally possess more scientific skills than girls

\begin{tabular}{|c|c|c|c|c|c|}
\hline \multicolumn{2}{|c|}{} & Frequency & Percent & Valid Percent & $\begin{array}{c}\text { Cumulative } \\
\text { Percent }\end{array}$ \\
\hline \multirow{3}{*}{ Valid } & Strongly Agree & 3 & 2.3 & 2.9 & 2.9 \\
\cline { 2 - 5 } & Agree & 16 & 12.2 & 15.4 & 18.3 \\
\cline { 2 - 5 } & Undecided & 16 & 12.2 & 15.4 & 33.7 \\
\cline { 2 - 5 } & Strongly Disagree & 13 & 9.9 & 12.5 & 46.2 \\
\cline { 2 - 6 } & Disagree & 56 & 42.7 & 53.8 & 100.0 \\
\cline { 2 - 6 } & Total & 104 & 79.4 & 100.0 & \\
\hline Missing & System & 27 & 20.6 & & \\
\hline \multicolumn{2}{|c|}{} & 131 & 100.0 & & \\
\hline
\end{tabular}

Table 4 results indicated that $69(66.3 \%)$ out of 104 teachers disagreed and strongly disagreed with the idea that boys generally possess more scientific skills than girls, $19(18.3 \%)$ of them agreed and 
strongly agreed with the same statement and $16(15.4 \%)$ of the participants were undecided. The mentioned results in table 4 showed that although the majority of teachers did not agree with boys possess more scientific skills than girls, we find that 35 (33.7\%) teachers out of 104 teachers were undecided and agreed with the studied statement which means that a considerable number of private teachers believe that males have scientific skills more than girls.

Table5 $\backslash 44.2 \%$ agree

Q5 Females are better in reading than their male counterpart

\begin{tabular}{|c|c|c|c|c|c|}
\hline \multicolumn{2}{|c|}{} & Frequency & Percent & Valid Percent & $\begin{array}{c}\text { Cumulative } \\
\text { Percent }\end{array}$ \\
\hline \multirow{3}{*}{ Valid } & Strongly Agree & 4 & 3.1 & 3.8 & 3.8 \\
\cline { 2 - 6 } & Agree & 46 & 35.1 & 44.2 & 48.1 \\
\cline { 2 - 6 } & Undecided & 11 & 8.4 & 10.6 & 58.7 \\
\cline { 2 - 6 } & Strongly Disagree & 5 & 3.8 & 4.8 & 63.5 \\
\cline { 2 - 6 } & Disagree & 38 & 29.0 & 36.5 & 100.0 \\
\cline { 2 - 6 } & Total & 104 & 79.4 & 100.0 & \\
\hline Missing & System & 27 & 20.6 & & \\
\hline
\end{tabular}

Table 5 results indicated that $43(41.3 \%)$ out of 104 teachers disagreed and strongly disagreed with females are better in reading than males, $50(48.0 \%)$ of them agreed and strongly agreed with the same statement and 11(10.6\%) of the participants were undecided. The mentioned results in table 5 showed that almost half of the teachers agreed that females are better in reading than males while the others $51.9 \%$ disagreed and were undecided with the same tested statement, which means that almost half of the private teachers believe that females are better in reading more than males.

Table6 $53.8 \%$ agree

Q6: Boys are naturally better at most Sports

\begin{tabular}{|c|c|c|c|c|c|}
\hline \multicolumn{2}{|c|}{} & Frequency & Percent & Valid Percent & $\begin{array}{c}\text { Cumulative } \\
\text { Percent }\end{array}$ \\
\hline \multirow{3}{*}{ Valid } & Strongly Agree & 9 & 6.9 & 8.7 & 8.7 \\
\cline { 2 - 6 } & Agree & 56 & 42.7 & 53.8 & 62.5 \\
\cline { 2 - 6 } & Undecided & 14 & 10.7 & 13.5 & 76.0 \\
\cline { 2 - 6 } & Strongly Disagree & 2 & 1.5 & 1.9 & 77.9 \\
\cline { 2 - 6 } & Disagree & 23 & 17.6 & 22.1 & 100.0 \\
\cline { 2 - 6 } & Total & 104 & 79.4 & 100.0 & \\
\hline Missing & System & 27 & 20.6 & & \\
\hline \multicolumn{2}{|c|}{} & 131 & 100.0 & & \\
\hline
\end{tabular}

Again table 6 indicated that $25(24.0 \%)$ out of 104 teachers disagreed and strongly disagreed with boys are naturally better at most sports, $65(62.5 \%)$ of them agreed and strongly agreed with the same statement and 14(13.5\%) of the participants were undecided. The mentioned results in table 6 showed that more than half of the teachers agreed that boys are naturally better at most sports while the other $(37.5 \%)$ were undecided and disagreed with the same tested statement, which means that the majority of the private teachers believe that boys are naturally better in sports more than girls.

Table7 $\backslash 52.9 \%$ disagree

Q7: Boys are more active and outspoken than girls

\begin{tabular}{|c|c|c|c|c|c|}
\hline \multicolumn{2}{|c|}{} & Frequency & Percent & Valid Percent & $\begin{array}{c}\text { Cumulative } \\
\text { Percent }\end{array}$ \\
\hline \multirow{3}{*}{ Valid } & Strongly Agree & 3 & 2.3 & 2.9 & 2.9 \\
\cline { 2 - 6 } & Agree & 25 & 19.1 & 24.0 & 26.9 \\
\cline { 2 - 6 } & Undecided & 14 & 10.7 & 13.5 & 40.4 \\
\cline { 2 - 6 } & Strongly Disagree & 7 & 5.3 & 6.7 & 47.1 \\
\cline { 2 - 6 } & Disagree & 55 & 42.0 & 52.9 & 100.0 \\
\cline { 2 - 6 } & Total & 104 & 79.4 & 100.0 & \\
\hline Missing & System & 27 & 20.6 & & \\
\hline \multicolumn{1}{|c|}{} & Total & 131 & 100.0 & & \\
\hline
\end{tabular}

Table 7 presented teachers choices to statement 7 which indicated that $62(59.6 \%)$ out of 104 teachers disagreed and strongly disagreed with the idea that boys are more active and outspoken than girls, 28 
(26.9 \%) of them agreed and strongly agreed with the same statement and $14(13.5 \%)$ of the participants were undecided. The mentioned results in table 7 showed that more than half of the teachers disagreed that boys are more active and outspoken than girls while the other $42(40.4 \%)$ were undecided and agreed with the same tested statement, which means that a considerable number $26.9 \%$ of the private teachers believe that boys are more active and more out spoken than girls.

Table8 $\backslash 42.3 \%$ agree

Q8: Girls are well dress and neat than boys

\begin{tabular}{|c|c|c|c|c|c|}
\hline \multicolumn{2}{|c|}{} & Frequency & Percent & Valid Percent & $\begin{array}{c}\text { Cumulative } \\
\text { Percent }\end{array}$ \\
\hline \multirow{3}{*}{ Valid } & Strongly Agree & 5 & 3.8 & 4.8 & 4.8 \\
\cline { 2 - 6 } & Agree & 44 & 33.6 & 42.3 & 47.1 \\
\cline { 2 - 6 } & Undecided & 15 & 11.5 & 14.4 & 61.5 \\
\cline { 2 - 6 } & Strongly Disagree & 2 & 1.5 & 1.9 & 63.5 \\
\cline { 2 - 6 } & Disagree & 38 & 29.0 & 36.5 & 100.0 \\
\cline { 2 - 6 } & Total & 104 & 79.4 & 100.0 & \\
\hline Missing & System & 27 & 20.6 & & \\
\hline \multicolumn{2}{|c|}{} & 131 & 100.0 & & \\
\hline
\end{tabular}

Table 8 presented our teachers` choices to statement 8 which indicated that 40 (38.4\%) out of 104 teachers disagreed and strongly disagreed with girls are well dress and neat than boys, $49(47.1 \%)$ of them agreed and strongly agreed with the same statement and $15(14.4 \%)$ of the participants were undecided. The mentioned results in table 8 showed that more than the third of the teachers disagreed that girls are well dressed and neater than boys while the other $49(47.1 \%)$ agreed with the same tested statement, which means that a considerable number of the private teachers discriminate between boys` and girls` neatness and well dressing.

Table9 40.4\% agree

Q9: Men should be the head of the family

\begin{tabular}{|c|c|c|c|c|c|}
\hline \multicolumn{2}{|c|}{} & Frequency & Percent & Valid Percent & $\begin{array}{c}\text { Cumulative } \\
\text { Percent }\end{array}$ \\
\hline \multirow{3}{*}{ Valid } & Strongly Agree & 13 & 9.9 & 12.5 & 12.5 \\
\cline { 2 - 6 } & Agree & 42 & 32.1 & 40.4 & 52.9 \\
\cline { 2 - 6 } & Undecided & 16 & 12.2 & 15.4 & 68.3 \\
\cline { 2 - 6 } & Strongly Disagree & 5 & 3.8 & 4.8 & 73.1 \\
\cline { 2 - 6 } & Disagree & 28 & 21.4 & 26.9 & 100.0 \\
\cline { 2 - 6 } & Total & 104 & 79.4 & 100.0 & \\
\hline Missing & System & 27 & 20.6 & & \\
\hline \multicolumn{1}{|c|}{} & 131 & 100.0 & & \\
\hline
\end{tabular}

More gender stereotyped belief was seen in table 9 results, where the teachers` choices to statement 9 indicated that $33(31.7 \%)$ out of 104 teachers disagreed and strongly disagreed with men should be the head of the family, 54 (52.9\%) of them agreed and strongly agreed with the same statement and $16(15.4 \%)$ of the participants were undecided. The mentioned results in table 9 showed that the majority of the teachers $54(52.9 \%)$ agreed that men should be the head of the family while only 33 $(31.7 \%)$ of them disagreed with the same tested statement, which means that most of the private teachers believe that men should be the authority of the family. In other words, they discriminate between males` and females` family roles.

Table10 51.9\% strongly disagree

Q10: Women's place is at home

\begin{tabular}{|c|c|c|c|c|c|}
\hline \multicolumn{2}{|c|}{} & Frequency & Percent & Valid Percent & $\begin{array}{c}\text { Cumulative } \\
\text { Percent }\end{array}$ \\
\hline \multirow{3}{*}{ Valid } & Strongly Agree & 1 & .8 & 1.0 & 1.0 \\
\cline { 2 - 6 } & Agree & 4 & 3.1 & 3.8 & 4.8 \\
\cline { 2 - 6 } & Undecided & 4 & 3.1 & 3.8 & 8.7 \\
\cline { 2 - 6 } & Strongly Disagree & 54 & 41.2 & 51.9 & 60.6 \\
\cline { 2 - 6 } & Disagree & 41 & 31.3 & 39.4 & 100.0 \\
\cline { 2 - 6 } & Total & 104 & 79.4 & 100.0 & \\
\hline Missing & System & 27 & 20.6 & & \\
\hline \multicolumn{2}{|c|}{} & 131 & 100.0 & & \\
\hline
\end{tabular}


A fair gender stereotyped belief was seen in table 10 results, where the teachers ` choices to statement 10 indicated that almost all participant $95(91.3 \%)$ out of 104 teachers disagreed and strongly disagreed with women`s place is at home, $5(4.8 \%)$ of them agreed and strongly agreed with the same statement and $4(3.8 \%)$ of the participants were undecided. The mentioned results in table 10 showed that the majority of the teachers disagreed that women should stay at home which can be referred to most of the private teachers were females as seen in the participants ' gender distribution table 0 .

Table11 Means of Beliefs

\begin{tabular}{|l|r|r|}
\hline \multicolumn{1}{|c|}{ Descriptive Statistics } & $\mathrm{N}$ & Mean \\
\hline \multicolumn{1}{|c|}{} & 104 & 4.01 \\
\hline 1-Boys can handle pressure situations better than girls. & 104 & 4.52 \\
\hline 2-Male are strong and female are weak. & 104 & 4.04 \\
\hline 3-Male students generally do better in mathematics than female students. & 104 & 3.99 \\
\hline 4-Boys generally possess more scientific skills than girls. & 104 & 3.26 \\
\hline 5-Females are better in reading than their male counterpart. & 104 & 2.75 \\
\hline 6-Boys are naturally better at most Sports. & 104 & 3.83 \\
\hline 7-Boys are more active and outspoken than girls. & 104 & 3.23 \\
\hline 8-Girls are well dressed and neater than boys. & 104 & 2.93 \\
\hline 9-Men should be the head of the family. & 104 & 4.25 \\
\hline 10-Women's place is at home. & 104 & \\
\hline Valid N (listwise) & \\
\hline
\end{tabular}

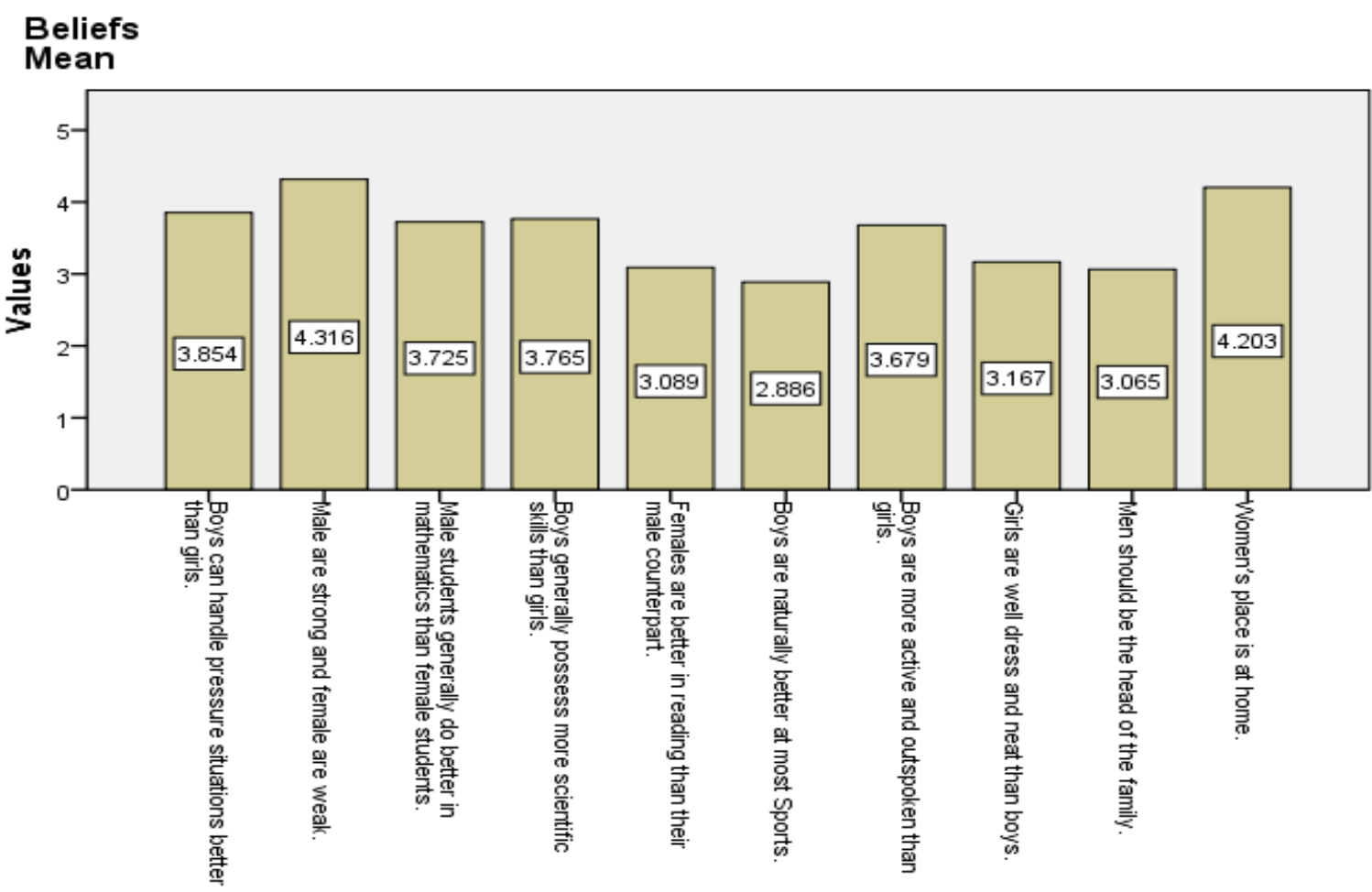

Chart 2

Table 11 and chart 2 demonstrated all the belief statement means that varied between 4.316 and 2.886 in which the highest mean noticed was for statement 2 where the majority of teachers disagreed that males are strong and females are weak, while the lowest was for statement 6 where the majority of teachers agreed that boys are naturally better at most sports.

Overall analysis to the findings of the teachers gender stereotyped beliefs revealed that the private school teachers had gender stereotyped beliefs in many statements. For instance, what was surprising is that the majority of teachers $(62.9 \%)$ agreed and strongly agreed with statement 9 and ( men should be the head of family) although almost all participants were working females. The same for statement 8 where only 40 teachers $(38.4 \%)$ out of 104 disagreed and strongly disagreed with girls are more well dressed and neat than boys, and65 of 104 participants (62.5\%) agreed and strongly agreed with statement 6 ( boys are naturally better and at sports) while the results of statement 5 showed that 50 
teachers $(48.0 \%)$ agreed and strongly agreed and 11(10.6\%) were undecided with females are better in reading than males. Furthermore, the results of the other statements showed fairness between males and females especially for mathematics and scientific skills and far away from gender stereotyped beliefs, almost all showed openness to working women as they all disagreed with statement 10 that women place is at home. In this way the study question number one was answered.

\section{Practice Descriptive Statistics}

In order to answer the question number 2 (What is the extent of the teachers` gender stereotyped practices in Beirut private classrooms? The following descriptive statistical operations were employed. Tables (12-24) showed the results of the frequencies percentages, and means used to determine the extent of their gender stereotyped practices and whether or not there is a statistically significant difference between teachers performance application of gender stereotyped practices in private schools.

Table12\44.2\% agree and 44.2\% Strongly Agree

Q11 Teachers should encourage male and female students to carry out the same activities

\begin{tabular}{|c|c|c|c|c|c|}
\hline & & Frequency & Percent & Valid Percent & Cumulative Percent \\
\hline \multirow[t]{5}{*}{ Valid } & Strongly Agree & 46 & 35.1 & 44.2 & 44.2 \\
\hline & Agree & 46 & 35.1 & 44.2 & 88.5 \\
\hline & Undecided & 5 & 3.8 & 4.8 & 93.3 \\
\hline & Disagree & 7 & 5.3 & 6.7 & 100.0 \\
\hline & Total & 104 & 79.4 & 100.0 & \\
\hline Missing & System & 27 & 20.6 & & \\
\hline \multicolumn{2}{|r|}{ Total } & 131 & 100.0 & & \\
\hline
\end{tabular}

The findings presented in table 12 indicated an overall agreement with the studied statement number 11 (Teachers should encourage male and female students to carry out the same activities), where 92 out of 104 teachers (88.4\%)strongly agreed and agreed with it, while only 7 (6.7\%) disagreed and 5 $(4.8 \%)$ were undecided with the same tested statement respectively. Analyzing these results showed that the private school teachers are largely aware of the gender stereotyped practices in terms of class activities.

\section{Table13\59.6\% Disagree}

Q 12 Teachers should devote more time to encouraging girls than boys

\begin{tabular}{|c|c|c|c|c|c|}
\hline & & Frequency & Percent & Valid Percent & Cumulative Percent \\
\hline \multirow[t]{6}{*}{ Valid } & Strongly Agree & 3 & 2.3 & 2.9 & 2.9 \\
\hline & Agree & 12 & 9.2 & 11.5 & 14.4 \\
\hline & Undecided & 16 & 12.2 & 15.4 & 29.8 \\
\hline & Strongly Disagree & 11 & 8.4 & 10.6 & 40.4 \\
\hline & Disagree & 62 & 47.3 & 59.6 & 100.0 \\
\hline & Total & 104 & 79.4 & 100.0 & \\
\hline Missing & System & 27 & 20.6 & & \\
\hline \multicolumn{2}{|r|}{ Total } & 131 & 100.0 & & \\
\hline
\end{tabular}

Again table 13 presented the results of statement 12 in which we find teachers aware of their gender stereotyped practices in their classrooms. $73(55.7 \%)$ out of 104 disagreed and strongly disagreed with teachers should devote more time to encourage girls than boys, while $15(14.4 \%)$ strongly agreed and agreed and 16(15.4\%) respectively were undecided with the tested statement.

Table14\44.2\% Agree

Q13 Girls/women should be encouraged to enter traditionally male jobs such as engineering, medicine or architecture

\begin{tabular}{|c|c|c|c|c|c|}
\hline & & Frequency & Percent & Valid Percent & Cumulative Percent \\
\hline \multirow[t]{6}{*}{ Valid } & Strongly Agree & 35 & 26.7 & 33.7 & 33.7 \\
\hline & Agree & 46 & 35.1 & 44.2 & 77.9 \\
\hline & Undecided & 9 & 6.9 & 8.7 & 86.5 \\
\hline & Strongly Disagree & 2 & 1.5 & 1.9 & 88.5 \\
\hline & Disagree & 12 & 9.2 & 11.5 & 100.0 \\
\hline & Total & 104 & 79.4 & 100.0 & \\
\hline Missing & System & 27 & 20.6 & & \\
\hline \multicolumn{2}{|r|}{ Total } & 131 & 100.0 & & \\
\hline
\end{tabular}


Table 14 results emphasized our teachers`awareness of avoiding gender stereotyped practices when the majority agreed and strongly agreed 81 (77.9\%)out of 104 teachers with statement 13 (Girls/women should be encouraged to enter traditionally male jobs such as engineering, medicine or architecture), while only $14(13.4 \%)$ and $9(8.7 \%)$ were undecided with the same statement respectively.

\section{Table15 $\backslash 47.1 \%$ Agree}

Q14There should be concerted efforts to raise students with a non-sexist orientation, at home and in schools

\begin{tabular}{|l|l|r|r|r|r|}
\hline \multicolumn{2}{|c|}{} & Frequency & \multicolumn{1}{c|}{ Percent } & Valid Percent & \multicolumn{2}{c|}{$\begin{array}{c}\text { Cumulative } \\
\text { Percent }\end{array}$} \\
\hline \multirow{4}{*}{ Valid } & Strongly Agree & 27 & 20.6 & 26.0 & 26.0 \\
\cline { 2 - 6 } & Agree & 49 & 37.4 & 47.1 & 73.1 \\
\cline { 2 - 6 } & Undecided & 19 & 14.5 & 18.3 & 91.3 \\
\cline { 2 - 6 } & Strongly Disagree & 1 & .8 & 1.0 & 92.3 \\
\cline { 2 - 6 } & Disagree & 8 & 6.1 & 7.7 & 100.0 \\
\cline { 2 - 6 } & Total & 104 & 79.4 & 100.0 & \\
\hline Missing & System & 27 & 20.6 & & \\
\hline Total & 131 & 100.0 & & \\
\hline
\end{tabular}

Again and again table 15 demonstrated the private school teachers` gender stereotyped practice focusing on the importance of raising a non sexiest orientation in both home and school environments, where $76(58 \%)$ out of 104 participants agreed and strongly agreed with statement 14 (There should be concerted efforts to raise students with a non-sexist orientation, at home and in schools), 9 (8.7\%) disagreed and strongly disagreed and $19(18.3 \%)$ were undecided with the studied statement. What was noticed here and in many previous studied statements was the considerable number of undecided teachers that can be explained by their being not sure that this issue should be avoided.

Table16 $\backslash 55.8 \%$ Agree

Q15Teachers should be involved in shaping their students' perceptions about gender roles

\begin{tabular}{|l|l|r|r|r|r|}
\hline \multicolumn{2}{|c|}{} & \multicolumn{1}{|c|}{ Frequency } & \multicolumn{1}{c|}{ Percent } & Valid Percent & \multicolumn{2}{c|}{$\begin{array}{c}\text { Cumulative } \\
\text { Percent }\end{array}$} \\
\hline \multirow{5}{*}{ Valid } & Strongly Agree & 19 & 14.5 & 18.3 & 18.3 \\
\cline { 2 - 6 } & Agree & 58 & 44.3 & 55.8 & 74.0 \\
\cline { 2 - 6 } & Undecided & 17 & 13.0 & 16.3 & 90.4 \\
\cline { 2 - 6 } & Strongly Disagree & 1 & .8 & 1.0 & 91.3 \\
\cline { 2 - 6 } & Disagree & 9 & 6.9 & 100.0 & 100.0 \\
\cline { 2 - 6 } & Total & 104 & 79.4 & & \\
\hline Missing & System & 27 & 20.6 & & \\
\hline Total & 131 & 100.0 & & \\
\hline
\end{tabular}

Similar to the previous results of practice statements table 16 showed that the majority of teachers 77 $(74.1 \%)$ out of 104 teachers agreed and strongly agreed with shaping their students ' perceptions about gender roles, while $10(9.7 \%)$ disagreed and strongly disagreed and 17 (16.3\%) were undecided with the studied statement number 15. Again the percentage and the number of undecided teachers should be taken into consideration which showed teachers` inability to claim their point of view toward gender stereotyped practices.

Table17 $\backslash 52.9 \%$ Agree

Q 16 Teachers should discourage students from acting out gender-stereotyped roles

\begin{tabular}{|l|l|l|l|l|l|}
\hline \multicolumn{2}{|c|}{} & Frequency & Percent & Valid Percent & Cumulative Percent \\
\hline Valid & Strongly Agree & 18 & 13.7 & 17.3 & 17.3 \\
\cline { 2 - 6 } & Agree & 55 & 42.0 & 52.9 & 70.2 \\
\cline { 2 - 6 } & Undecided & 22 & 16.8 & 21.2 & 91.3 \\
\cline { 2 - 6 } & Strongly Disagree & 1 & .8 & 1.0 & 92.3 \\
\cline { 2 - 6 } & Disagree & 8 & 6.1 & 7.7 & 100.0 \\
\cline { 2 - 6 } & Total & 104 & 79.4 & 100.0 & \\
\hline Missing & System & 27 & 20.6 & & \\
\hline Total & 131 & 100.0 & & \\
\hline
\end{tabular}


Contradicting the track where teachers proved their awareness of avoiding gender stereotyped practices in their class, we find them discouraging students from acting gender stereotyped roles. Table 17 results indicated that the majority of teachers agreed and strongly agreed $73(70.2 \%)$ with statement 16 (Teachers should discourage students from acting out gender-stereotyped roles), while 9 $(8.7 \%)$ strongly disagreed and disagreed, and 22(21.2\%) were undecided with the same statement respectively, which showed also a big number of undecided teachers who were not sure whether to discourage or encourage students from acting gender stereotyped roles.

Table18 $\backslash 46.2 \%$ Agree

Q17 Boys and girls should be given equal opportunity and not treated differently

\begin{tabular}{|c|c|c|c|c|c|}
\hline \multicolumn{2}{|c|}{} & Frequency & Percent & Valid Percent & $\begin{array}{c}\text { Cumulative } \\
\text { Percent }\end{array}$ \\
\hline \multirow{3}{*}{ Valid } & Strongly Agree & 44 & 33.6 & 42.3 & 42.3 \\
\cline { 2 - 6 } & Agree & 48 & 36.6 & 46.2 & 88.5 \\
\cline { 2 - 6 } & Undecided & 5 & 3.8 & 4.8 & 93.3 \\
\cline { 2 - 6 } & Strongly Disagree & 2 & 1.5 & 1.9 & 95.2 \\
\cline { 2 - 6 } & Disagree & 5 & 3.8 & 4.8 & 100.0 \\
\cline { 2 - 6 } & Total & 104 & 79.4 & 100.0 & \\
\hline Missing & System & 27 & 20.6 & & \\
\hline \multicolumn{2}{|c|}{} & 131 & 100.0 & & \\
\hline
\end{tabular}

Back to the participants awareness of avoiding gender stereotyped practices as table 18 showed; almost all agreed and strongly agreed $92(88.5 \%$ ) with statement 17 (boys and girls should be given equal opportunity and not treated differently), while 7 (6.7\%) disagreed and strongly disagreed and $5(4.8 \%)$ were undecided with the tested statement respectively.

Table19 $\backslash 56.7 \%$ Agree

Q18 I use gender equitable language in my lessons

\begin{tabular}{|l|l|r|r|r|r|}
\hline \multicolumn{2}{|c|}{} & Frequency & \multicolumn{1}{c|}{ Percent } & Valid Percent & \multicolumn{2}{c|}{$\begin{array}{c}\text { Cumulative } \\
\text { Percent }\end{array}$} \\
\hline \multirow{3}{*}{ Valid } & Strongly Agree & 24 & 18.3 & 23.1 & 23.1 \\
\cline { 2 - 6 } & Agree & 59 & 45.0 & 56.7 & 79.8 \\
\cline { 2 - 6 } & Undecided & 13 & 9.9 & 12.5 & 92.3 \\
\cline { 2 - 6 } & Strongly Disagree & 2 & 1.5 & 1.9 & 94.2 \\
\cline { 2 - 6 } & Disagree & 6 & 4.6 & 5.8 & 100.0 \\
\cline { 2 - 6 } & Total & 104 & 79.4 & 100.0 & \\
\hline Missing & System & 27 & 20.6 & & \\
\hline Total & 131 & 100.0 & & \\
\hline
\end{tabular}

Moreover, answers to statement 18 showed that teachers were able to express their classroom practices away from gender stereotyping their students through using equitable language when addressing them. Table 19 results presented 83 (79.8\%) out of 104 teachers agreed and strongly agreed with statement 18 (I use gender equitable language in my lessons), while 8 ( 7.7\%) disagreed and strongly disagreed, and $13(12.5 \%)$ of them were undecided with the studied statement respectively.

Table20 $150.0 \%$ Agree

Q 191 obtain and use instructional materials which are gender neutral in my lessons

\begin{tabular}{|l|l|r|r|r|r|}
\hline \multicolumn{2}{|c|}{} & \multicolumn{1}{|c|}{ Frequency } & \multicolumn{1}{c|}{ Percent } & Valid Percent & \multicolumn{2}{c|}{$\begin{array}{c}\text { Cumulative } \\
\text { Percent }\end{array}$} \\
\hline \multirow{3}{*}{ Valid } & Strongly Agree & 22 & 16.8 & 21.2 & 21.2 \\
\cline { 2 - 6 } & Agree & 52 & 39.7 & 50.0 & 71.2 \\
\cline { 2 - 6 } & Undecided & 19 & 14.5 & 18.3 & 89.4 \\
\cline { 2 - 6 } & Strongly Disagree & 2 & 1.5 & 1.9 & 91.3 \\
\cline { 2 - 6 } & Disagree & 9 & 6.9 & 100.0 & \\
\cline { 2 - 6 } & Total & 104 & 79.4 & & \\
\hline Missing & System & 27 & 20.6 & & \\
\hline Total & 131 & 100.0 & & \\
\hline
\end{tabular}


Similar to the previous results of practice statements table 20 showed that the majority of teachers 74 (71.2\%) of 104 teachers agreed and strongly agreed with statement 19 (I obtain and use instructional materials which are gender neutral in my lessons), while 11 (10.6\%) disagreed and strongly disagreed and $19(18.3 \%)$ were undecided with the studied statement. Again the percentage and the number of undecided teachers should be taken into consideration which shows teachers` inability to claim their point of view toward gender stereotyped practices.

Table21 $\backslash 51.9 \%$ Agree

Q 20 I try to discourage gender stereotyped behavior in my classes

\begin{tabular}{|l|l|r|r|r|r|}
\hline \multicolumn{2}{|c|}{} & Frequency & Percent & Valid Percent & \multicolumn{2}{c|}{$\begin{array}{c}\text { Cumulative } \\
\text { Percent }\end{array}$} \\
\hline \multirow{3}{*}{ Valid } & Strongly Agree & 24 & 18.3 & 23.1 & 23.1 \\
\cline { 2 - 6 } & Agree & 54 & 41.2 & 51.9 & 75.0 \\
\cline { 2 - 6 } & Undecided & 19 & 14.5 & 18.3 & 93.3 \\
\cline { 2 - 6 } & Strongly Disagree & 1 & .8 & 1.0 & 94.2 \\
\cline { 2 - 6 } & Disagree & 6 & 4.6 & 5.8 & 100.0 \\
\cline { 2 - 6 } & Total & 104 & 79.4 & 100.0 & \\
\hline Missing & System & 27 & 20.6 & & \\
\hline Total & 131 & 100.0 & & \\
\hline
\end{tabular}

On the same track with previous results of practice statements table 21 showed that the majority of teachers $78(75.0 \%)$ of 104 teachers agreed and strongly agreed with statement 20 (I try to discourage gender stereotyped behavior in my classes), while $7(1.0 \%)$ disagreed and strongly disagreed and 19 (18.3\%) were undecided with the studied statement respectively. Again the number and the percentage of undecided teachers was remarkable which could be explained either as a lack of knowledge about the right practices or rejecting the idea of dealing with students as equal human beings and practicing with them according to their sexes.

Table22 $\backslash 49.0 \%$ strongly Agree

Q21 My classroom practices encourage students to respect other gender

\begin{tabular}{|l|l|r|r|r|r|}
\hline \multicolumn{2}{|c|}{} & Frequency & \multicolumn{1}{|c|}{ Percent } & Valid Percent & \multicolumn{2}{c|}{$\begin{array}{c}\text { Cumulative } \\
\text { Percent }\end{array}$} \\
\hline \multirow{7}{*}{ Valid } & Strongly Agree & 51 & 38.9 & 49.0 & 49.0 \\
\cline { 2 - 6 } & Agree & 47 & 35.9 & 45.2 & 94.2 \\
\cline { 2 - 6 } & Undecided & 5 & 3.8 & 4.8 & 99.0 \\
\cline { 2 - 6 } & Strongly Disagree & 1 & .8 & 1.0 & 100.0 \\
\cline { 2 - 6 } & Total & 104 & 79.4 & 100.0 & \\
\hline Missing & System & 27 & 20.6 & & \\
\hline Total & 131 & 100.0 & & \\
\hline
\end{tabular}

Again teachers proved their ideal classroom practices to reach the peak away from gender stereotyping their students as demonstrated in table 22 results, where 98 (94.2\%) of 104 teachers agreed and strongly agreed with statement 21( my classroom practices encourage students to respect other gender), while $1(1.0 \%)$ strongly disagreed and disagreed, and 5(4.8\%) were undecided with the studied statement respectively.

Table23 $\backslash 62.5 \%$ Agree

$Q 22$ Every student needs to learn about gender issues

\begin{tabular}{|c|c|c|c|c|c|}
\hline \multicolumn{2}{|c|}{} & Frequency & Percent & Valid Percent & Cumulative Percent \\
\hline \multirow{3}{*}{ Valid } & Strongly Agree & 24 & 18.3 & 23.1 & 23.1 \\
\cline { 2 - 6 } & Agree & 65 & 49.6 & 62.5 & 85.6 \\
\cline { 2 - 6 } & Undecided & 15 & 11.5 & 14.4 & 100.0 \\
\cline { 2 - 6 } & Total & 104 & 79.4 & 100.0 & \\
\hline Missing & System & 27 & 20.6 & & \\
\hline \multicolumn{2}{|c|}{} & 131 & 100.0 & & \\
\hline
\end{tabular}

Similar results were continued in table 23 where the majority $89(85.6 \%)$ out of 104 teachers agreed and strongly agreed with statement 22 (Every student needs to learn about gender issues), while no one disagreed or strongly disagrees and again 15 (14.4\%) were undecided with the studied statement. 
Table24. Classroom Practice Means

\begin{tabular}{|l|l|l|}
\hline \multicolumn{1}{|c|}{ Descriptive Statistics } & N & Mean \\
\hline \multicolumn{1}{|c|}{} & 104 & 1.81 \\
\hline 11-Teachers should encourage male and female students to carry out the same activities. & 104 & 4.12 \\
\hline 12-Teachers should devote more time to encouraging girls than boys. & 104 & 2.13 \\
\hline $\begin{array}{l}\text { 13-Girls/women should be encouraged to enter traditionally male jobs such as engineering, } \\
\text { medicine or architecture. }\end{array}$ & 104 & 2.17 \\
\hline $\begin{array}{l}\text { 14-There should be concerted efforts to raise students with a non-sexist orientation, at home } \\
\text { and in schools. }\end{array}$ & 104 & 2.26 \\
\hline 15-Teachers should be involved in shaping their students' perceptions about gender roles. & 104 & 2.29 \\
\hline 16-Teachers should discourage students from acting out gender-stereotyped roles. & 104 & 1.81 \\
\hline 17-Boys and girls should be given equal opportunity and not treated differently. & 104 & 2.11 \\
\hline 18-I use gender equitable language in my lessons. & 104 & 2.27 \\
\hline 19-I obtain and use instructional materials which are gender neutral in my lessons. & 104 & 2.14 \\
\hline 20-I try to discourage gender stereotyped behavior in my classes. & 104 & 1.58 \\
\hline 21-My classroom practices encourage students to respect other gender. & 104 & 1.91 \\
\hline 22-Every student needs to learn about gender issues. & 104 & \\
\hline Valid N (listwise) & \\
\hline
\end{tabular}

\section{Descriptive Statistics \\ Mean}

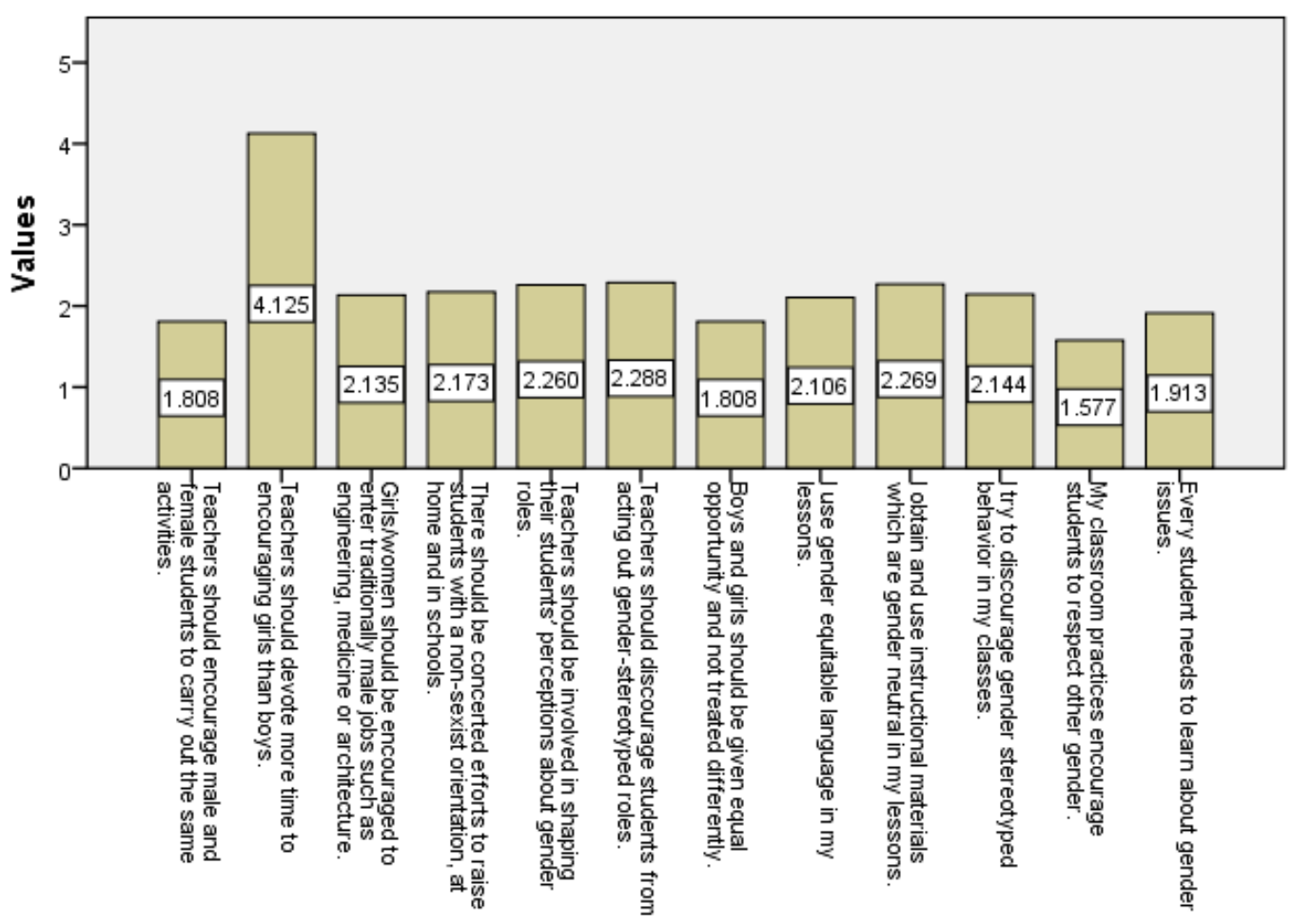

\section{Chart 3}

Table 24 and chart 3 demonstrated the mean scores for all practice statements where the lowest mean was 1.57 for statement 21 followed by the mean score 1.80 for statement 11 and the mean score 1.91 for statement 22. In other words these mean results showed that the majority of the teachers were practicing the three contexts away from gender stereotyping students. Moreover, the highest mean score 4.125 was for statement 12 (teachers should devote more time to encourage girls than boys) where table 13 demonstrated teachers' aware of their gender stereotyped practices in their classrooms through the number $73(55.7 \%)$ of disagreed and disagreed strongly teachers who refused to give more time for girls than boys. The other mean scores showed less interest in gender stereotyped practices but still unexpectedly satisfy the requirement to avoid dealing with the two genders in different ways. 
In conclusion to this part, surprisingly almost none of these statement results could show serious behavior gaps in our participated teachers ' practices in private school classrooms. Contradicting the track where teachers proved their awareness of avoiding gender stereotyped practices in their classes, we find them discouraging students from acting other gender stereotyped roles. This could be explained as teachers` objections to their students` choices that do not fit their genders in other words they wanted them to be attached to their traditional assigned roles as shown in table 17 where the majority of teachers agreed and strongly agreed 73 (70.2\%) with statement 16 (teachers should discourage students from acting out gender-stereotyped roles), which created a gap in the participants' gender stereotyped practices. More to be mentioned about this part is the big numbers noticed of undecided teachers in most of the statements which could be explained by fear of expressing their traditional point of view about treating students of the two genders in the same way.

Finally after all these detailed analysis we can consider the study question number 2 was answered.

\section{Awareness Descriptive Statistics}

In order to answer question 3 of this study (What is the level of the participant teachers`awareness of gender stereotyping students in private schools? The following descriptive statistical operations were employed. Tables (25-31) showed the results of the frequencies percentages, and means used to determine the extent of the participants` awareness of gender stereotyping students and whether or not there is a statistically significant difference between teachers performance application of gender stereotyped awareness in private schools.

Table25 $\backslash 58.7 \%$ Agree

Q 23 Awareness about the gender-stereotyped issues should be incorporated into all school subjects

\begin{tabular}{|l|l|r|r|r|r|}
\hline \multicolumn{2}{|c|}{ Valid } & Frequency & Percent & Valid Percent & Cumulative Percent \\
\cline { 2 - 6 } & Strongly Agree & 21 & 16.0 & 20.2 & 20.2 \\
\cline { 2 - 6 } & Agree & 61 & 46.6 & 58.7 & 78.8 \\
\cline { 2 - 6 } & Undecided & 17 & 13.0 & 16.3 & 95.2 \\
\cline { 2 - 6 } & Disagree & 5 & 3.8 & 4.8 & 100.0 \\
\cline { 2 - 6 } & Total & 104 & 79.4 & 100.0 & \\
\hline Missing & System & 27 & 20.6 & & \\
\hline Total & 131 & 100.0 & & \\
\hline
\end{tabular}

Table 25 results demonstrated a strong call for schools to incorporate awareness of gender stereotyped issues in all classes, where $82(78.9 \%)$ of the 104 participants agreed and strongly agreed with statement 23 (Awareness about the gender-stereotyped issues should be incorporated into all school subjects) while 5(4.8\%) only disagreed and strongly disagreed and $17(16.3 \%)$ were undecided with the studied statement.

Table26 53.8\% Agree

Q24 Schools and government are not doing enough at the moment to create awareness about gender issues in Lebanon

\begin{tabular}{|c|c|c|c|c|c|}
\hline & & Frequency & Percent & Valid Percent & $\begin{array}{c}\text { Cumulative } \\
\text { Percent }\end{array}$ \\
\hline \multirow[t]{6}{*}{ Valid } & Strongly Agree & 17 & 13.0 & 16.3 & 16.3 \\
\hline & Agree & 56 & 42.7 & 53.8 & 70.2 \\
\hline & Undecided & 24 & 18.3 & 23.1 & 93.3 \\
\hline & Strongly Disagree & 1 & .8 & 1.0 & 94.2 \\
\hline & Disagree & 6 & 4.6 & 5.8 & 100.0 \\
\hline & Total & 104 & 79.4 & 100.0 & \\
\hline Missing & System & 27 & 20.6 & & \\
\hline \multicolumn{2}{|r|}{ Total } & 131 & 100.0 & & \\
\hline
\end{tabular}

Similar results were shown in table 26 where the majority of the participant teachers $73(70.1 \%)$ seemed complaining about the governments defaults in certain gender awareness in Lebanon schools, while $7(6.8 \%)$ disagreed and strongly disagreed and 24 (23.1\%) were undecided with the studied statement 24 respectively. Again we could notice that the undecided teachers were a remarkable number to be considered. 
Investigating Teachers Gender Stereotyped Performance in Beirut Private Schools

Table27 $\backslash 53.8 \%$ Agree

Q25 Awareness about the gender-stereotyped issues should be incorporated into all homes

\begin{tabular}{|l|l|r|r|r|r|}
\hline \multicolumn{2}{|c|}{} & Frequency & \multicolumn{1}{|c|}{ Percent } & Valid Percent & \multicolumn{2}{c|}{$\begin{array}{c}\text { Cumulative } \\
\text { Percent }\end{array}$} \\
\hline \multirow{3}{*}{ Valid } & Strongly Agree & 21 & 16.0 & 20.2 & 20.2 \\
\cline { 2 - 6 } & Agree & 56 & 42.7 & 53.8 & 74.0 \\
\cline { 2 - 6 } & Undecided & 20 & 15.3 & 19.2 & 93.3 \\
\cline { 2 - 6 } & Strongly Disagree & 2 & 1.5 & 1.9 & 95.2 \\
\cline { 2 - 6 } & Disagree & 5 & 3.8 & 4.8 & 100.0 \\
\cline { 2 - 6 } & Total & 104 & 79.4 & 100.0 & \\
\hline Missing & System & 27 & 20.6 & & \\
\hline Total & & 131 & 100.0 & & \\
\hline
\end{tabular}

Table 27 results demonstrated another strong call but this time for parents at home to incorporate awareness of gender stereotyped issues in all their behavior, where 77 (74.0\%) of the 104 participants agreed and strongly agreed with statement 25 (Awareness about the gender-stereotyped issues should be incorporated into all homes) while 7(6.7\%) only disagreed and strongly disagreed and $20(19.2 \%)$ were undecided with the studied statement. Again around 20\% of our participants were undecided which could reflect their innate traditional opinions about gender stereotyping.

Table28 $\backslash 66.3 \%$ Agree

Q26 Teacher education program should foster awareness of gender-stereotyped issues

\begin{tabular}{|l|l|r|r|r|r|}
\hline \multicolumn{2}{|c|}{ Valid } & \multicolumn{1}{|c|}{ Frequency } & \multicolumn{1}{c|}{ Percent } & Valid Percent & Cumulative Percent \\
\cline { 2 - 6 } & Strongly Agree & 14 & 10.7 & 13.5 & 13.5 \\
\cline { 2 - 6 } & Agree & 69 & 52.7 & 66.3 & 79.8 \\
\cline { 2 - 6 } & Undecided & 18 & 13.7 & 17.3 & 97.1 \\
\cline { 2 - 6 } & Disagree & 3 & 2.3 & 2.9 & 100.0 \\
\cline { 2 - 6 } & Total & 104 & 79.4 & 100.0 & \\
\hline Missing & System & 27 & 20.6 & & \\
\hline Total & 131 & 100.0 & & \\
\hline
\end{tabular}

Table 28 results presented a new type of call for education program designers to include gender stereotype awareness, where $83(79.8 \%)$ of the 104 participants agreed and strongly agreed with statement 26 (Teacher education program should foster awareness of gender)while $3(2.9 \%)$ only disagreed and strongly disagreed and $18(17.3 \%)$ were undecided with the studied statement. Again $17.3 \%$ of our participants were undecided which could reflect their traditional opinions about gender stereotyping,

\section{Table29\60.6\% Agree}

Q27 Teacher education program should prepare students to deal with gender-stereotyped and bias in classroom and school

\begin{tabular}{|l|l|r|r|r|r|}
\hline \multicolumn{2}{|c|}{} & \multicolumn{1}{|c|}{ Frequency } & \multicolumn{1}{c|}{ Percent } & Valid Percent & Cumulative Percent \\
\hline \multirow{3}{*}{ Valid } & Strongly Agree & 20 & 15.3 & 19.2 & 19.2 \\
\cline { 2 - 6 } & Agree & 63 & 48.1 & 60.6 & 79.8 \\
\cline { 2 - 6 } & Undecided & 18 & 13.7 & 17.3 & 97.1 \\
\cline { 2 - 6 } & Disagree & 3 & 2.3 & 2.9 & 100.0 \\
\cline { 2 - 6 } & Total & 104 & 79.4 & 100.0 & \\
\hline Missing & System & 27 & 20.6 & & \\
\hline \multicolumn{2}{|l|}{ Total } & 131 & 100.0 & & \\
\hline
\end{tabular}

Table 29 results demonstrated another strong call but this time to include teachers` education program with materials that help students deal with gender stereotyped and bias in classrooms and schools. Results of statement 27 shown in table 29 indicated $83(79.8 \%)$ of the 104 private teachers agreed and strongly agreed, while 3(2.9 \%) only disagreed and strongly disagreed and $18(17.3 \%)$ were undecided with the studied statement respectively. Again around $17.3 \%$ of our participants were undecided which could be referred to their different opinion that could not be accepted by the environment they are living in. 
Investigating Teachers Gender Stereotyped Performance in Beirut Private Schools

Table30 $56.7 \%$ Agree

Q28 Teacher education program should promote gender sensitive behavior

\begin{tabular}{|l|l|r|r|r|r|}
\hline \multicolumn{2}{|c|}{} & Frequency & Percent & Valid Percent & \multicolumn{2}{|c|}{$\begin{array}{c}\text { Cumulative } \\
\text { Percent }\end{array}$} \\
\hline \multirow{3}{*}{ Valid } & Strongly Agree & 19 & 14.5 & 18.3 & 18.3 \\
\cline { 2 - 6 } & Agree & 59 & 45.0 & 56.7 & 75.0 \\
\cline { 2 - 6 } & Undecided & 20 & 15.3 & 19.2 & 94.2 \\
\cline { 2 - 6 } & Strongly Disagree & 1 & .8 & 1.0 & 95.2 \\
\cline { 2 - 6 } & Disagree & 5 & 3.8 & 4.8 & 100.0 \\
\cline { 2 - 6 } & Total & 104 & 79.4 & 100.0 & \\
\hline Missing & System & 27 & 20.6 & & \\
\hline Total & 131 & 100.0 & & \\
\hline
\end{tabular}

Table 30 results demonstrated another strong call to include the teacher education program stimulate gender sensitive behavior, where $78(75.0 \%)$ of the 104 participants agreed and strongly agreed with statement 28 (Teacher education program should promote gender sensitive behavior) while $6(5.8 \%)$ only disagreed and strongly disagreed and $20(19.2 \%)$ were undecided with the studied statement.

Table31. Awareness Mean Scores

\begin{tabular}{|c|c|c|}
\hline \multicolumn{3}{|l|}{ Descriptive Statistics } \\
\hline & $\mathrm{N}$ & Mean \\
\hline $\begin{array}{l}\text { 23- Awareness about the gender-stereotyped issues should be incorporated into all school } \\
\text { subjects. }\end{array}$ & 104 & 2.11 \\
\hline $\begin{array}{l}\text { 24- Schools and government are not doing enough at the moment to create awareness } \\
\text { about gender issues in Lebanon. }\end{array}$ & 104 & 2.26 \\
\hline $\begin{array}{l}\text { 25- Awareness about the gender-stereotyped issues should be incorporated into all } \\
\text { homes. }\end{array}$ & 104 & 2.17 \\
\hline 26- Teacher education program should foster awareness of gender -stereotyped issues. & 104 & 2.12 \\
\hline $\begin{array}{l}\text { 27- Teacher education program should prepare students to deal with gender-stereotyped } \\
\text { and bias in classroom and school. }\end{array}$ & 104 & 2.07 \\
\hline 28- Teacher education program should promote gender sensitive behavior. & 104 & 2.17 \\
\hline Valid N (listwise) & 104 & \\
\hline
\end{tabular}

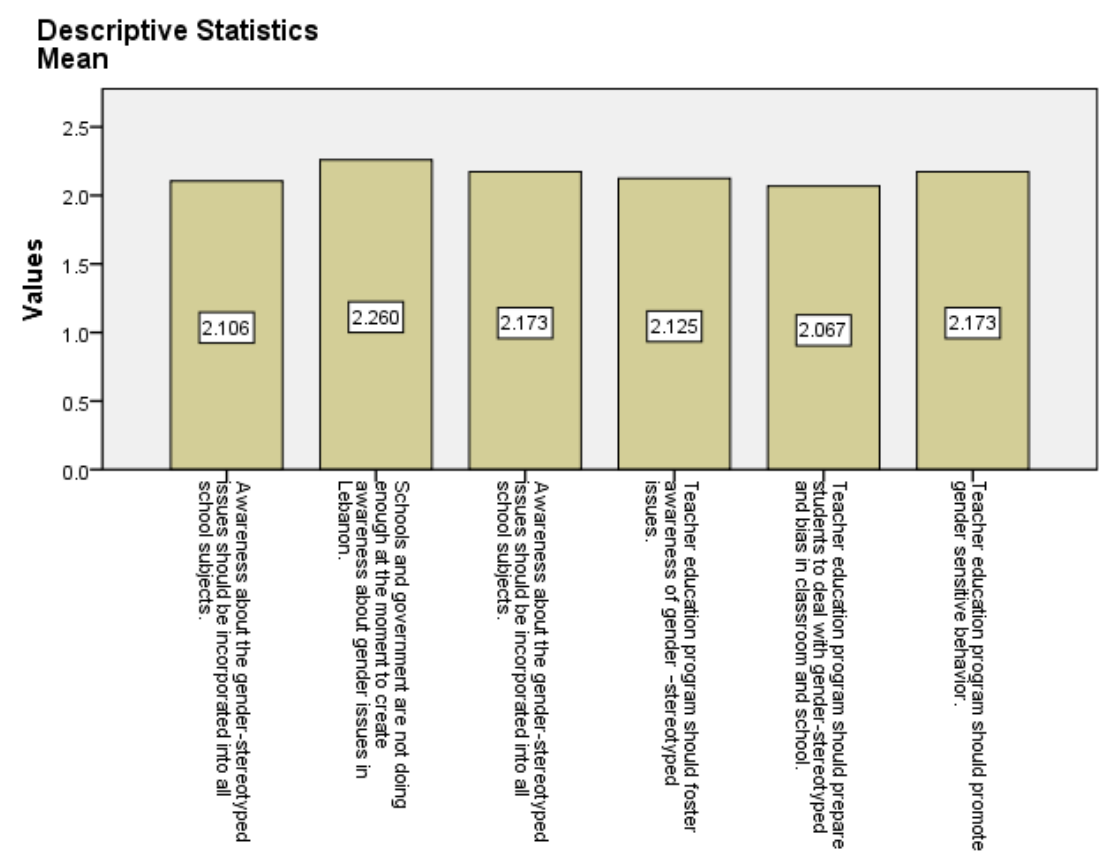

Chart 4

Table 31 and chart 4 demonstrated the mean scores for all awareness statement answers where all means looked similar and varied between 2.067 and 2.260, which is fair enough as almost all participants reacted toward all statements in the same way. In other words these mean results reflected the statistical strongly agreed teachers wiall the statement.. Moreover, all teachers were able to 
express their needs through their calls to the Lebanese government to train them how to be more aware of gender stereotyped bias and to afford them with the suitable materials and include their education programs with solutions for all gender stereotyped issues.

In conclusion to this part, surprisingly almost all this part statement results showed that our participant private teachers level of awareness of gender stereotyped issues was up to the standard of expressing their needs through calls to the government and teacher education program designers to support them with the right materials solutions and activities to avoid the sensitivity of gender stereotyped issues. More to be mentioned about this part is the big numbers noticed of undecided teachers in most of the statements which could be explained by fear of expressing their traditional point of view toward treating students of the two genders in the same way.

After all what was analyzed in this part we can say that question 3 of this study was answered.

The findings analyzed so far revealed that, despite the variability in teachers' choices, respondents generally agreed with the majority of awareness and practice statements while their responses to the gender stereotyped beliefs showed that they had many gender stereotyped attitudes.

\section{Correlation Statistics}

In order to answer question 4 of this study (What is the correlation between the participants gender and experience with their beliefs, practices and awareness?), the following descriptive statistical operations were employed. Tables (32-40) revealed the results of the Means, Standard Deviation, Correlations, Ttest, ANOVA, and Pearson to determine the correlation between teachers` gender and experience and teachers`gender stereotyped beliefs, practices and awareness.

\section{Compare Means Test to Compare Beliefs, Classroom Practices and Awareness with Respect to} Gender (male, female)

\section{Variable Means According to Gender}

Table32. Compare Means Test Report

\begin{tabular}{|l|l|l|l|l|}
\hline \multicolumn{2}{|c|}{ Compare Means Test Gender } & \multicolumn{1}{c|}{ Belief } & Classroom Practices & Awareness \\
\hline \multirow{2}{*}{ Male } & Mean & 3.5455 & 2.4773 & 2.4394 \\
\cline { 2 - 5 } & Std. Deviation & .57335 & .75193 & .73889 \\
\hline \multirow{2}{*}{ Female } & Mean & 3.6968 & 2.1864 & 2.1165 \\
\cline { 2 - 5 } & Std. Deviation & .62301 & .47736 & .61079 \\
\hline \multirow{2}{*}{ Total } & Mean & 3.6808 & 2.2171 & 2.1506 \\
\cline { 2 - 5 } & Std. Deviation & .61708 & .51624 & .62943 \\
\hline
\end{tabular}

Table 32 showed that the males means for belief was 3.5455 and standard deviation .57335 , while for practices the mean was 2.4773 and standard deviation.75193, and for the awareness the mean was 2.4394and standard deviation .73889. As for females the belief mean was 3.6968 and the standard deviations was .62301, while the practice mean was 2.1864 and the standard deviation was .47736 and their mean score for awareness was 2.1165 and their standard deviation was .61079. These results indicated that the highest means for both genders were for beliefs while for practice and awareness they were almost the same, which means that the participants suffered from gender stereotyped beliefs.

Table33. ANOVA Test Table for Gender and other Variable

\begin{tabular}{|c|c|c|c|c|c|c|c|}
\hline & & & $\begin{array}{l}\text { Sum of } \\
\text { Squares }\end{array}$ & Df & $\begin{array}{l}\text { Mean } \\
\text { Square }\end{array}$ & $\mathrm{F}$ & Sig. \\
\hline $\begin{array}{l}\text { Belief * } \\
\text { gender }\end{array}$ & $\begin{array}{l}\text { Between } \\
\text { Groups }\end{array}$ & (Combined) & .225 & 1 & .225 & .589 & .445 \\
\hline & Within $\mathrm{Gr}$ & & 38.996 & 102 & .382 & & \\
\hline & Total & & 39.222 & 103 & & & \\
\hline $\begin{array}{l}\text { Classroom } \\
\text { Practices * }\end{array}$ & $\begin{array}{l}\text { Between } \\
\text { Groups }\end{array}$ & (Combined) & .832 & 1 & .832 & 3.190 & .077 \\
\hline gender & Within $\mathrm{Gr}$ & & 26.618 & 102 & .261 & & \\
\hline & Total & & 27.450 & 103 & & & \\
\hline $\begin{array}{l}\text { Awareness * } \\
\text { gender }\end{array}$ & $\begin{array}{l}\text { Between } \\
\text { Groups }\end{array}$ & (Combined) & 1.026 & 1 & 1.026 & 2.630 & .077 \\
\hline & Within $\mathrm{Gr}$ & & 39.781 & 102 & .390 & & \\
\hline & Total & & 40.807 & 103 & & & \\
\hline
\end{tabular}


Again a one-way ANOVA conducted revealed that the significance between teachers ' beliefs and gender was. 445 while practice and awareness were similar in significance .077 which means that they are significantly different from beliefs. The overall analysis of this table 33 showed that there is no significant difference between gender and the three variables belief.

Table34. Measures of Association

\begin{tabular}{|l|r|r|}
\hline & Eta & Eta Squared \\
\hline Belief * gender & .076 & .006 \\
\hline Classroom Practices * gender & .174 & .030 \\
\hline Awareness * gender & .159 & .025 \\
\hline
\end{tabular}

More about associations between gender and teachers stereotyped beliefs, practices and awareness were indicated in table 34 in which the belief 'showed the lowest Eta .076 and Eta Squared .006, while for practice it was .174 and .030 and for awareness .159 and .025respectively. Thus, these results showed a variety of association differences between gender and belief, practice as well as awareness.

Table35\ One Sample T-Test for the three DVs

\begin{tabular}{|l|r|r|r|r|}
\hline & $\mathrm{N}$ & \multicolumn{1}{|c|}{ Mean } & \multicolumn{1}{c|}{ Std. Deviation } & \multicolumn{1}{l|}{ Std. Error Mean } \\
\hline Belief & 104 & 2.2171 & .61708 & .06051 \\
\hline Classroom Practices & 104 & 2.2171 & .51624 & .05062 \\
\hline Awareness & 104 & 2.1506 & .62943 & .06172 \\
\hline
\end{tabular}

$\mathrm{T}$ test results for the three variables (belief practice and awareness) demonstrated awareness to have the lowest mean 2.1506 then 2.2171 for the practice and the highest was for belief 2.2171 which means that participants agreed with all awareness statements, while they agreed with the majority of practice statements and the least agreed with the belief statements.

Table36. One-Sample Test

\begin{tabular}{|l|c|r|r|r|r|r|}
\hline \multirow{2}{*}{} & \multicolumn{9}{|c|}{ Test Value $=0$} \\
\cline { 2 - 7 } & $\mathrm{T}$ & Df & \multirow{2}{*}{$\begin{array}{c}\text { Sig. (2- } \\
\text { tailed) }\end{array}$} & $\begin{array}{c}\text { Mean } \\
\text { Difference }\end{array}$ & \multicolumn{2}{|c|}{$\begin{array}{c}\text { 95\% Confidence Interval of } \\
\text { the Difference }\end{array}$} \\
\cline { 5 - 7 } & & & & & Lower & Upper \\
\hline Belief & 60.829 & 103 & .000 & 3.68077 & 3.5608 & 3.8008 \\
\hline Classroom Practices & 43.798 & 103 & .000 & 2.21715 & 2.1168 & 2.3175 \\
\hline Awareness & 34.845 & 103 & .000 & 2.15064 & 2.0282 & 2.2730 \\
\hline
\end{tabular}

Table37. Mean and Standard Deviation for Awareness

\begin{tabular}{|l|l|r|}
\hline N & Valid & 104 \\
\cline { 2 - 3 } & Missing & 27 \\
\hline Mean & 2.1506 \\
\hline Std. Deviation & .62943 \\
\hline
\end{tabular}

Table 36 demonstrated the various $\mathrm{T}$ test results for the three variables: belief 60.829 , practice 43.798 and awareness 34.845 in which the significance for the variables was less than 0.01 . while table 37 results showed that the Standard Deviation of awareness responses was .62943 and the Mean $=2.15$ which indicated that the majority of the private school teachers agreed with all the awareness statements to avoid gender stereotyped behaviors with students.

Table38. Pearson Correlation

\begin{tabular}{|c|c|c|c|c|}
\hline & & Belief & $\begin{array}{l}\text { Classroom } \\
\text { Practices }\end{array}$ & Awareness \\
\hline \multirow[t]{3}{*}{ Belief } & Pearson Correlation & 1 & .061 & -.102 \\
\hline & Sig. (2-tailed) & & .539 & .305 \\
\hline & $\mathrm{N}$ & 104 & 104 & 104 \\
\hline \multirow[t]{3}{*}{ Classroom Practices } & Pearson Correlation & .061 & 1 & $.595^{* * *}$ \\
\hline & Sig. (2-tailed) & .539 & & .000 \\
\hline & $\mathrm{N}$ & 104 & 104 & 104 \\
\hline \multirow[t]{3}{*}{ Awareness } & Pearson Correlation & -.102 & $.595^{* *}$ & 1 \\
\hline & Sig. (2-tailed) & .305 & .000 & \\
\hline & $\mathrm{N}$ & 104 & 104 & 104 \\
\hline
\end{tabular}

**. Correlation is significant at the 0.01 level (2-tailed)

International Journal of Humanities Social Sciences and Education (IJHSSE) 
Pearson Correlation results shown in table 38 indicated that there is a correlation between the private school teachers` awareness and their classroom practices as results revealed a significant correlation less than 0.01. The same table demonstrated the results of Pearson Correlation between teachers beliefs and their awareness where the correlation significance was greater than 0.01 which means that there is no correlation between awareness and beliefs

Table39 Correlations $\backslash$ Years of Experience and Other Variables

\begin{tabular}{|l|l|r|r|r|r|}
\hline \multicolumn{2}{|c|}{} & $\begin{array}{c}\text { Years of } \\
\text { Experience }\end{array}$ & \multicolumn{1}{c|}{ Belief } & \multicolumn{1}{c|}{$\begin{array}{c}\text { Classroom } \\
\text { Practices }\end{array}$} & Awareness \\
\hline \multirow{2}{*}{$\begin{array}{l}\text { Years of } \\
\text { Experience }\end{array}$} & Pearson Correlation & 1 & -.024 & .162 & .075 \\
\cline { 2 - 6 } & Sig. (2-tailed) & & .806 & .099 & .449 \\
\cline { 2 - 6 } & $\mathrm{N}$ & 131 & 104 & 104 & 104 \\
\hline
\end{tabular}

**. Correlation is significant at the 0.01 level (2-tailed)

Table 39 results showed that Pearson Correlation between the participants years of experience and beliefs is -.024and Sig. (2-tailed). 806, while Pearson Correlation between their years of experience and practices was .162and Sig. (2-tailed).099, and Pearson Correlation between years of experience and awareness was .075 and the Sig. (2-tailed) was .449where all are greater than 0.01 , which means that there is no correlation between the teachers' years of experience and their gender stereotyped awareness, practices and beliefs.

Table40. Correlations $\backslash$ Gender and Other Variable

\begin{tabular}{|c|c|c|c|c|c|}
\hline & & gender & Belief & $\begin{array}{l}\text { Classroom } \\
\text { Practices }\end{array}$ & Awareness \\
\hline \multirow[t]{3}{*}{ Gender } & Pearson Correlation & 1 & .076 & -.174 & -.159 \\
\hline & Sig. (2-tailed) & & .445 & .077 & .108 \\
\hline & $\mathrm{N}$ & 131 & 104 & 104 & 104 \\
\hline
\end{tabular}

**. Correlation is significant at the 0.01 level (2-tailed)

Table 40 indicated no significant results between gender and the three variables. The analyzed table showed that Pearson Correlation between gender and beliefs was 0.076 and Sig. (2-tailed) 0.445, while the correlation between gender and practices was -.174 and Sig. (2-tailed) 0.77, and the correlation between gender and awareness was -.159 and the Sig. (2-tailed) 0.108 where all were greater than 0.01 , which means that there was no correlation between the teachers' gender and their gender stereotyped awareness, practices and beliefs.

Consequently, the study question number 4 was answered through the above studied tables and indicated that no significant difference existed in teachers' gender-stereotyped beliefs practice and awareness based on gender and years of experience, which means that teachers from private schools were aware of their gender-stereotyped practices and the necessary changes should occur to overcome the gender stereotyped bias at schools.

\section{DisCUSSION AND CONCLUSION}

Through the detailed analysis presented and explained in all tables, we can say that the study participants were gender-stereotyping teachers in terms of their beliefs while their practices and awareness showed understanding to the studied issue. If taken into consideration the number of undecided participants compared to those who agreed and strongly agreed, we can reveal that a considerable number of the private school teachers were practicing gender stereotyped behaviors with students. Statement 3 table 3 can be a good indicator to this practice of gender stereotyped behaviors where we find that the number of undecided participants equaled the ones who agreed and strongly agreed with $16 \%$ each. This equality in percentage presents that whether the undecided participants are with or without, that can affect some students, if not all, negatively through this gender stereotyped belief. Similarly, when we went over the practice part results we found that the majority showed fairness between genders, at the same time we could find that there are some teachers who confessed openly their gender stereotyping practices while others expressed their opinions as undecided which is also a fault in education. Mostly, teachers`choices varied between $70 \%$ and $90 \%$ for those who agreed and strongly agreed with the statements, the question to be raised here: What about the others? Do they form any negative effect on students or not? The answer to this question 
was derived from the wide range of literature that discussed the effects of gender stereotyped behaviors or beliefs on students. Accordingly, Martin \& Ruble (2004), claimed that gender stereotype could be developed or released by teachers, making the school years a critical period to deal with students away from gender stereotypes. They added when teachers adopted negative gender stereotyped practices in classes, students potential growth and development were limited and their self-esteem and academic performance were affected negatively. In the same sense, Carlson, Egeland, \& Sroufe, (2004) explained to teachers, who might not notice the negative effects of their gender stereotyping students, and warned them of the negative consequences that become most apparent during adolescence after a long-term of gender bias effects.

The study results proved clearly the findings mentioned through literature of reinforcement regarding the traditional gender roles in the educational system where most book authors, contexts, content, words and pictures were more addressed to males than females. Additionally, it demonstrated the participants ' gender stereotyped beliefs and some of their gender stereotyped practices supported by all the repetitive considerable numbers, which varied between $15 \%$ and $23 \%$, of undecided participants. These were evidences of the existence of the teachers` gender stereotyped behaviors in the Lebanese private schools. For instance, the majority of the teachers showed that they had genderstereotyped beliefs and at the same time they were trying to prove their awareness to avoid their gender stereotyped practices. In other words, it was clear enough that they were trying their best to show that they were avoiding the reflection of their gender stereotyped beliefs in their practices. They were guilty in one of their gender-stereotyped practices when almost all agreed that they discouraged students from playing other gender roles which contradicts to their answers to statements 11 and 13 in the practice part. This contradiction revealed their understanding to each gender role as inherited from their traditional social beliefs of gender roles. Teachers tried to deny through their answers to the practice statements that they maintained unfair gender practices with males and females while we found them in the awareness part calling for changes and help to overcome the gender stereotyped bias in classes, homes and schools. Contradicting Hallam \& Ireson, (2003) who found that teachers' beliefs and practices were affected by their years of experience and their gender, the present study correlations between gender or years of experience and the three studied variables indicated no significant differences between them. For more details, the teachers' gender and years of experience did not affect their gender stereotyped attitudes, behavior and awareness which were supported by Mathew (2007). Similar to the findings of many researchers (Tatar \& Emmanuel, 2001; Sahin et al., 2002; and Tantekin, 2002) our results demonstrated various significant differences between teachers' gender stereotyped awareness, beliefs, and practices toward students. However, but the most realized difference was between teachers` beliefs from\one side and their practices and awareness on the other side .

The majority of the teachers' choices to the conducted questionnaire have given a good impression of their gender stereotyped practices in terms of language, activities, treatment and awareness. However, we find them fail in expressing their gender stereotyped beliefs when the majority agreed with men being the head of the family, men are naturally better in sports, girls are well dressed and neater than boys. Concerning beliefs also, almost all disagreed with the statement women `s place is at home which means they encourage equity with man that they believe he should be the head of the family. Moreover, the important evidence found in the study results was the undecided considerable number of participants in almost all statements which could be related to the contradictions found in the community we are living. No one can deny that Lebanon has been suffering for decades from many religious, economic, political and social contradictions which affected the population negatively and ended them up to be unsettled, unstable, lost, worried, fearing the unknown, and so on. More important conclusions could be derived from this study other than the significant differences between teachers' awareness of gender stereotyped beliefs and practices, were the necessary implications to acquire gender sensitivity knowledge, skills and developed attitudes in classroom layout for schools teachers, classroom practices and school administration. These could be summed up by the need for a sensitive awareness of gender issues at schools and homes achieved through professional teacher training, workshops, creating a gender balanced curriculum, developing the teaching education programs and school culture. Therefore, it is recommended that our teachers must learn to recognize and eliminate gender bias in their student teachers interactions both within and outside the classroom. When teachers become aware of their gender-biased beliefs /practices and aware of all required changes they can combat this bias and will be able to promote gender equity in their classrooms and 
society. Al this cannot be achieved unless all educators headed by the ministry of education cooperate to overcome this dangerous issue that may lead our generations to the unknown. Finally, we can say that this study results cannot be generalized as it was limited to six schools and the studied issue requires more investigations.

\section{REFERENCES}

[1] Aladejana, F O. (2002) Gender equality in science classroom: Curriculum implications for sustainable development. Nigerian Journal of Curriculum Studies, 9 (2): 85-91.

[2] Ayodeji, Ifegbesan, (2010). Gender-Stereotypes Belief and Practices in the Classroom: The Nigerian PostPrimary School Teachers'. Global Journal of Human Social Science, Vol.10(ver 1.0) Issue 4, 29 -38 GJHSS Classification- A (FOR) 130102,130105,130313.

[3] Azikwe, U. (2002) Mainstreaming in the curriculum for sustainable educational development. Nigerian Journal of Curriculum Studies, 9 (2): 100-121.

[4] Bronfenbrenner, U., \& Bronfenbrenner, U. (1979). The ecology of human development: Experiments by nature and design. Harvard university press.

[5] Hamre, B. K., \& Pianta, R. C. (2001). Early teacher-child relationships and the trajectory of children's school outcomes through eighth grade. Child Development, 72(2), 625-638.

[6] Calvanese, M. Mathew. (2007) Investigating gender stereotypes in elementary education. Journal of Undergraduate Psychological Research, vol2, 11-18.

[7] Cahill, B., \& Adams, E. (1997). An exploratory study of early childhood teachers' attitudes toward gender roles. Sex Roles, 36 517-529.

[8] Diekman, A. B \& Eagly, A. H (2000) Stereotypes as dynamic constructs: Women and men of the past, present and future. Personality and social psychology Bulletin, 26, 1171-1188.

[9] Erinosho S.Y (2005) Women in Science. An Inaugural lecture delivered at Olabisi Onabanjo University, Ago-Iwoye. Sept 13, 2005

[10] Fiske, S. T. (1993). Social cognition and social perception. Annual Review of Psychology, 44, 155-194.

[11] Fung, A., \& Ma, E. (2000). Formal vs. informal use of television and gender-rote stereotyping in Hong Kong. Sex Roles, 42, 57-81.

[12] Gray, C., \& Leith, H (2004) Perpetuating gender stereotypes in the classroom: a teacher perspective Educational Studies, 30, (1): 3 - 17.

[13] Hallam, S., \& Ireson, J. (2003) Secondary school teachers' attitudes towards and beliefs about ability grouping. British Journal of Educational Psychology, 73 (3): 343-356.

[14] Hoang, T. N. (2008) The effect of grade level, gender and ethnicity on attitude and learning environment in mathematics in High school. International Electronic Journal of Mathematics Education, 3(1): 48-59.

[15] Jones, S. M., \& Dindia, K. (2004) A Meta-Analytic Perspective on Sex Equity in the Classroom. Review of Educational Research, 74 (4): 443-471.

[16] Matthew M. Calvanese,(2007). Investigating Gender Stereotypes in Elementary Education. Journal of Undergraduate Psychological Research, Vol. 2, 11-18. Calvanese Western Connecticut State University.

[17] Martin, C., \& Ruble, D. (2004). Children's search for gender cues: Cognitive perspectives on gender development. Current Directions in Psychological Science, 13 (2), 67-70.

[18] Marshall, H. \& Arnot, M. (2008). Globalizing the School Curriculum: Gender, EFA and Global Citizenship Education. RECOUP Working Paper No. 17, UK.

[19] Mirza, M., Keynan, H. \& Fakhar-ud-din (2006) Gender Analysis of School Curriculum and Textbooks. UNSECO, Islamabad, 2004.

[20] Mkuchu, G. V. (2003) towards eliminating gender roles stereotyping in Tanzania Primary school Textbooks: Research Evidence from Social Studies Textbooks. UNESCO Conference on Intercultural Education. 15-18, June, Jyvaskyla, Finland.

[21] Ogunbanwo, I. O (1998) Assessing Gender factors in Secondary School Physics textbooks in Ogun State. Unpublished M. Ed Thesis submitted to Olabisi Onabanjo University, Ago-Iwoye.

[22] Orth, U., Robins, R. W., \& Widaman, K. F. (2012). Life-span development of self-esteem and its effects on important life outcomes. Journal of personality and social psychology, 102(6), 1271.

[23] Razumnikova, O. M. (2005). The interaction between gender stereotypes and life values as factors in the choice of profession. Russian Education and Society, 47, 21-33.

[24] Sadker, M., \& Sadker, D. (1986). Sexism in the classroom: From grade school to graduate school. Phi Delta Kapan, 67, 512-515. 
[25] Sadker, M., Sadker, D., \& Klein, S. (2001). The issue of gender in elementary and secondary education. Review of Research in Education, 17, 269-334.

[26] Stangor, C., \& Lange, I. E. (1994). Mental representations of social groups: Advances in understanding stereotypes and stereotyping. Advances in Experimental Social Psychology, 26, 357-416

[27] Subrahmanian, R. (2002). Gender and Education; A review of issues for social policy. Social Policy and Development Program Paper Number 9, United Nations Research Institute for Social Development.

[28] Tatar, M. \& Emmanuel, G. (2001). Teachers' perceptions of their students' gender roles. Journal of Educational Research, 94 (4): 215-224.

[29] Tiedemann, J. (2002). Teachers' Gender Stereotypes as Determinants of Teacher Perceptions in Elementary School Mathematics. Educational Studies in mathematics 50 (1): 49-62.

[30] Wentzel, K. R. (2003). Sociometric status and adjustment in middle school: A longitudinal study. The Journal of Early Adolescence, 23(1), 5-28.

[31] White, M. J. \& White, G. B. (2006) Implicit and explicit occupational gender stereotypes. Sex Roles, 55, 259-266.

Citation: Mona Mohamad Taher Tahseldar "Investigating Teachers Gender Stereotyped Performance in Beirut Private Schools" International Journal of Humanities Social Sciences and Education (IJHSSE), vol 5, no. 8, 2018, pp. 244-268. doi: http://dx.doi.org/10. $20431 / 2349-0381.0508021$.

Copyright: (C) 2018 Authors. This is an open-access article distributed under the terms of the Creative Commons Attribution License, which permits unrestricted use, distribution, and reproduction in any medium, provided the original author and source are credited. 